\title{
Scleractinia (Cnidaria: Anthozoa) from INDEMARES 2010-2012 expeditions to the Avilés Canyon System (Bay of Biscay, Spain, northeast Atlantic)
}

\author{
Álvaro Altuna · Pilar Ríos
}

Received: 31 January 2014/Revised: 7 May 2014/ Accepted: 10 May 2014/Published online: 30 May 2014

(C) Springer-Verlag Berlin Heidelberg and AWI 2014

\begin{abstract}
Twenty-eight species of scleractinian corals were collected between 55 and 2,291 m depth during INDEMARES 2010-2012 expeditions to the Avilés Canyon System and the near continental shelf (Bay of Biscay). Most interesting species are described and all depicted. All species were already known from the northeast Atlantic, although some are seldom reported. Deltocyathus eccentricus and Flabellum chunii are northernmost records in the eastern Atlantic, and species first collected from the Bay of Biscay. From a literature review and new records given herein, 31 species of Scleractinia are known from the Avilés Canyon System. Live specimens of six species were recorded outside their previously known bathymetric ranges in the Bay of Biscay and nearby areas, either at shallower depths (Caryophyllia sarsiae, Monomyces pygmaea, Stephanocyathus nobilis), or deeper depths (C. atlantica, $C$. sarsiae, Enallopsammia rostrata, Solenosmilia variabilis). Desmophyllum cristagalli has the widest bathymetric range (551-2,291 m), and Lophelia pertusa is the most widely distributed species (24 stations). Tabulating the number of live species occurring in each 100-m depth interval of the canyon system, highest species richness occurs in the 700-800-, 800-900-, and 1,400-1,500-m depth intervals (11 species). The habitat-forming species $L$. pertusa and
\end{abstract}

Communicated by H.-D. Franke.

Á. Altuna $(\bowtie)$

INSUB, Museo de Okendo, Zemoria 12, Apdo. 3223,

20013 Donostia-San Sebastián, Spain

e-mail: alvaro.altuna@telefonica.net

P. Ríos

Centro Oceanográfico de Gijón, Instituto Español de Oceanografía, Príncipe de Asturias 70 bis, 33212 Gijón, Spain e-mail: pilar.rios.lopez@gmail.com
Madrepora oculata were abundant in some stations building well-developed coral banks. Live colonies of the big-sized species $S$. variabilis and E. rostrata co-occurred at the deepest station sampled that yielded scleractinia $(2,291 \mathrm{~m})$.

Keywords Scleractinia - Avilés Canyon - Bay of Biscay · Spain

\section{Introduction}

During 2010-2012, the Spanish Institute of Oceanography (IEO) sampled the north-Iberian bathyal benthos within the INDEMARES AVILÉS project (Fig. 1). The main target of this project is an inventory of areas of biological interest for conservation purposes (Sánchez Delgado and Serrano 2010). Sampling was focused on the Avilés Canyon System, which is located very close to the coast off the city of Avilés (Bay of Biscay, north of Spain). It is one of the deepest canyons in the world (Louzao et al. 2010) and has a great biological production and biodiversity (Cristobo et al. 2009; Sánchez 2009; Sánchez et al. 2012). The canyon is in fact formed by a system of several subcanyons. One of them, La Gaviera Canyon, has well-preserved deepwater coral banks with a diversified fauna (see Sánchez et al. 2014).

Scleractinians have been studied in the canyon system and the shelf nearby since the 1990s, with 18 species known (Álvarez Claudio 1993, 1994, COCACE project; Louzao et al. 2010, COCACE project; Altuna 2013, ECOMARG project). The canyon is located within the region named "Southern Bay of Biscay" (I, $45^{\circ} \mathrm{N}-43^{\circ} \mathrm{N}$ ) by $\mathrm{Zi}-$ browius (1980) (see also Cairns and Chapman 2001). This author mentioned 34 species in this region, a number that 




Fig. 1 Study area sampled during the INDEMARES AVILÉS project. Portuguese border is not shown

has increased significantly after updating with 45 species currently known (see Altuna 2012, 2013).

In the present work, the scleractinians collected in the INDEMARES AVILÉS 2010-2012 expeditions to the canyon and the near continental shelf besides the head of the canyon are studied, and the most interesting species are described. All the species identified were already reported from the northeast Atlantic, but some of them are rarely cited corals or northernmost records. Despite the important previous studies in the area, the size and complexity of the Avilés Canyon System allow new remarkable discoveries even for the Bay of Biscay fauna, whose southern sector has been the subject of numerous expeditions and has one of the most diverse scleractinian faunas in the northeast Atlantic.

\section{Materials and methods}

The surveys were carried out by the Spanish Institute of Oceanography (IEO) during the years 2010-2012 in the Avilés Canyon System (Bay of Biscay, northeastern Atlantic) (Fig. 1). Details of stations, cartography and sampling gears used in the expeditions are given by Acosta Yepes and Sánchez Delgado (2010) and Sánchez Delgado and Serrano (2010). The list of stations with scleractinian corals is given in Table 1, and the list of species in Table 2. Sampling in the 2012 surveys was direct with a ROV (Remote Operated Vehicle) Liropus 2000 (Sánchez et al. 2012).

The material was collected at a depth interval of $55-2,291 \mathrm{~m}$ and preserved on board in ethanol $70 \%$. Specimens were alive unless otherwise stated. As some of the species studied herein were described recently from north-Iberian material (see Altuna 2013), only uncommon or scarcely recorded corals are redescribed. Synonyms and citations subsequent to Zibrowius (1980) are mainly focused in an area extended from $42^{\circ} \mathrm{N}$ to $48^{\circ} 30^{\prime} \mathrm{N}$ and westward to roughly $10^{\circ} \mathrm{W}$ and the Galicia Bank (Bay of Biscay and nearby areas, see Altuna 2010, 2013), and are given only from those species not dealt with by Altuna (2013). We refer to this author and to Zibrowius (1980) for prior synonyms and records.

Morphological terms (Cairns 1989, 1991, 1994; Reyes et al. 2009): H, height; GCD, great calicular diameter; LCD, lesser calicular diameter; GCD: LCD, ratio of greater to lesser calicular diameters; $\mathrm{Cx}, \mathrm{Px}, \mathrm{Sx}$, costae, pali or septa, of cycle designated by numerical script; $\mathrm{PD}$, pedicel diameter; PD: GCD, ratio of pedicel to greater calicular diameter. Sx $>$ Sy, septa of cycle $x$ wider than those of cycle $y$.

IEO: Spanish Institute of Oceanography. P-: spring survey; V-: summer survey; O-: autumn survey; DR-: rock dredge; V-: beam trawl; G-: otter trawl. 
Table 1 INDEMARES

2010-2012 expeditions, Avilés Canyon System
Stations with scleractinians. P-, spring; V-, summer; O-:

autumn; DR-: rock dredge; G-: otter trawl; V-: beam trawl. + ) Unidentifiable material (fragments, juveniles), or material unavailable for the authors

\begin{tabular}{|c|c|c|c|c|c|}
\hline Station & Expedition & Coordinates & Date & Depth (m) & No sp. \\
\hline DR03-A0410 & P-2010 & $43^{\circ} 56.7060^{\prime} \mathrm{N}-05^{\circ} 49.5960^{\prime} \mathrm{W}$ & 23.04 .2010 & 893 & 8 \\
\hline DR04-A0410 & P-2010 & $43^{\circ} 55.9480^{\prime} \mathrm{N}-05^{\circ} 45.7270^{\prime} \mathrm{W}$ & 26.04 .2010 & 700 & 7 \\
\hline DR05-A0410 & P-2010 & $43^{\circ} 56.0810^{\prime} \mathrm{N}-05^{\circ} 46.0650^{\prime} \mathrm{W}$ & 28.04 .2010 & 688 & 2 \\
\hline DR06-A0410 & P-2010 & $43^{\circ} 56.0440^{\prime} \mathrm{N}-05^{\circ} 46.1390^{\prime} \mathrm{W}$ & 28.04 .2010 & 790 & 2 \\
\hline DR07-A0410 & P-2010 & $43^{\circ} 46.2510^{\prime} \mathrm{N}-06^{\circ} 11.0020^{\prime} \mathrm{W}$ & 01.05 .2010 & 1,150 & $2+$ \\
\hline DR08-A0410 & P-2010 & $43^{\circ} 47.0180^{\prime} \mathrm{N}-06^{\circ} 11.7330^{\prime} \mathrm{W}$ & 02.05 .2010 & 844 & 3 \\
\hline DR11-A0410 & P-2010 & $43^{\circ} 44.7390^{\prime} \mathrm{N}-06^{\circ} 10.6090^{\prime} \mathrm{W}$ & 03.05 .2010 & 636 & 2 \\
\hline DR12-A0410 & P-2010 & $43^{\circ} 51.8340^{\prime} \mathrm{N}-06^{\circ} 25.9510^{\prime} \mathrm{W}$ & 05.05 .2010 & 828 & 6 \\
\hline DR15-A0410 & P-2010 & $43^{\circ} 51.4720^{\prime} \mathrm{N}-06^{\circ} 15.7340^{\prime} \mathrm{W}$ & 06.05 .2010 & 1,660 & 5 \\
\hline DR16-A0410 & P-2010 & $43^{\circ} 57.4800^{\prime} \mathrm{N}-06^{\circ} 10.4850^{\prime} \mathrm{W}$ & 06.05 .2010 & 1,818 & 1 \\
\hline DR17-A0410 & P-2010 & $43^{\circ} 56.2220^{\prime} \mathrm{N}-06^{\circ} 27.0100^{\prime} \mathrm{W}$ & 07.05 .2010 & 1,476 & 2 \\
\hline DR18-A0410 & P-2010 & $43^{\circ} 59.7810^{\prime} \mathrm{N}-05^{\circ} 34.7600^{\prime} \mathrm{W}$ & 08.05 .2010 & 767 & 4 \\
\hline DR19-A0410 & P-2010 & $43^{\circ} 57.5700^{\prime} \mathrm{N}-06^{\circ} 36.1030^{\prime} \mathrm{W}$ & 09.05 .2010 & 533 & + \\
\hline DR21-A0410 & P-2010 & $44^{\circ} 01.6790^{\prime} \mathrm{N}-06^{\circ} 32.9310^{\prime} \mathrm{W}$ & 10.05 .2010 & 1,744 & 1 \\
\hline DR22-A0410 & P-2010 & $44^{\circ} 05.4660^{\prime} \mathrm{N}-05^{\circ} 24.8050^{\prime} \mathrm{W}$ & 11.05 .2011 & 2,291 & 4 \\
\hline DR23-A0410 & P-2010 & $44^{\circ} 02.2780^{\prime} \mathrm{N}-05^{\circ} 55.9300^{\prime} \mathrm{W}$ & 12.05 .2010 & 1,706 & 1 \\
\hline DR24-A0410 & P-2010 & $44^{\circ} 01.9540^{\prime} \mathrm{N}-05^{\circ} 54.8040^{\prime} \mathrm{W}$ & 12.05 .2010 & 1,533 & $4+$ \\
\hline DR01-A0710 & V-2010 & $43^{\circ} 46.793^{\prime} \mathrm{N}-06^{\circ} 10.481^{\prime} \mathrm{W}$ & 29.07.2010 & 810 & $1+$ \\
\hline DR03-A0710 & V-2010 & $43^{\circ} 48.890^{\prime} \mathrm{N}-06^{\circ} 01.007^{\prime} \mathrm{W}$ & 29.07.2010 & 143 & 1 \\
\hline DR04-A0710 & V-2010 & $43^{\circ} 46.463^{\prime} \mathrm{N}-05^{\circ} 59.000^{\prime} \mathrm{W}$ & 30.07 .2010 & 128 & 2 \\
\hline DR05-A0710 & V-2010 & $43^{\circ} 46.132^{\prime} \mathrm{N}-05^{\circ} 59.621^{\prime} \mathrm{W}$ & 30.07 .2010 & 128 & + \\
\hline DR06-A0710 & V-2010 & $43^{\circ} 45.128^{\prime} \mathrm{N}-06^{\circ} 09.207^{\prime} \mathrm{W}$ & 31.07 .2010 & 649 & 3 \\
\hline DR08-A0710 & V-2010 & $43^{\circ} 45.314^{\prime} \mathrm{N}-06^{\circ} 11.184^{\prime} \mathrm{W}$ & 01.08 .2010 & 800 & 4 \\
\hline DR09-A0710 & V-2010 & $43^{\circ} 44.789^{\prime} \mathrm{N}-06^{\circ} 11.239^{\prime} \mathrm{W}$ & 01.08 .2010 & 626 & 1 \\
\hline DR10-A0710 & V-2010 & $43^{\circ} 43.898^{\prime} \mathrm{N}-06^{\circ} 05.981^{\prime} \mathrm{W}$ & 01.08 .2010 & 342 & 2 \\
\hline DR12-A0710 & V-2010 & $43^{\circ} 43.600^{\prime} \mathrm{N}-06^{\circ} 08.685^{\prime} \mathrm{W}$ & 02.08 .2010 & 843 & 3 \\
\hline DR13-A0710 & V-2010 & $43^{\circ} 58.306^{\prime} \mathrm{N}-05^{\circ} 47.212^{\prime} \mathrm{W}$ & 03.08 .2010 & 769 & 3 \\
\hline DR14-A0710 & V-2010 & $44^{\circ} 01.394^{\prime} \mathrm{N}-05^{\circ} 42.383^{\prime} \mathrm{W}$ & 03.08 .2010 & 772 & + \\
\hline DR15-A0710 & V-2010 & $43^{\circ} 59.354^{\prime} \mathrm{N}-05^{\circ} 48.541^{\prime} \mathrm{W}$ & 04.08 .2010 & 1,228 & 4 \\
\hline DR16-A0710 & V-2010 & $44^{\circ} 01.509^{\prime} \mathrm{N}-05^{\circ} 42.898^{\prime} \mathrm{W}$ & 05.08 .2010 & 928 & 1 \\
\hline DR01-A0511 & P-2011 & $43^{\circ} 46.249^{\prime} \mathrm{N}-05^{\circ} 55.594^{\prime} \mathrm{W}$ & 02.05 .2011 & 103 & 1 \\
\hline DR03-A0511 & P-2011 & $43^{\circ} 55.118^{\prime} \mathrm{N}-05^{\circ} 45.950^{\prime} \mathrm{W}$ & 03.05 .2011 & 776 & 5 \\
\hline DR04-A0511 & P-2011 & $43^{\circ} 59.584^{\prime} \mathrm{N}-05^{\circ} 43.915^{\prime} \mathrm{W}$ & 04.05 .2011 & 593 & 8 \\
\hline DR05-A0511 & P-2011 & $43^{\circ} 59.376^{\prime} \mathrm{N}-05^{\circ} 46.649^{\prime} \mathrm{W}$ & 04.05 .2011 & 908 & $7+$ \\
\hline DR06-A0511 & P-2011 & $43^{\circ} 56.199^{\prime} \mathrm{N}-05^{\circ} 35.501^{\prime} \mathrm{W}$ & 05.05 .2011 & 462 & 2 \\
\hline DR07-A0511 & P-2011 & $43^{\circ} 52.662^{\prime} \mathrm{N}-05^{\circ} 54.436^{\prime} \mathrm{W}$ & 06.05 .2011 & 551 & 4 \\
\hline DR08-A0511 & P-2011 & $43^{\circ} 39.475^{\prime} \mathrm{N}-06^{\circ} 03.491^{\prime} \mathrm{W}$ & 07.05 .2011 & 55 & 1 \\
\hline DR09-A0511 & P-2011 & $43^{\circ} 40.254^{\prime} \mathrm{N}-06^{\circ} 04.622^{\prime} \mathrm{W}$ & 07.05 .2011 & 86 & 1 \\
\hline G01-A0511 & P-2011 & $43^{\circ} 50.305^{\prime} \mathrm{N}-06^{\circ} 11.882^{\prime} \mathrm{W}$ & 11.05 .2011 & 361 & 2 \\
\hline G02-A0511 & P-2011 & $43^{\circ} 54.971^{\prime} \mathrm{N}-06^{\circ} 15.253^{\prime} \mathrm{W}$ & 12.05 .2011 & 1,051 & 1 \\
\hline G03-A0511 & P-2011 & $43^{\circ} 57.869^{\prime} \mathrm{N}-06^{\circ} 28,112^{\prime} \mathrm{W}$ & 13.05 .2011 & 1,464 & 3 \\
\hline G04-A0511 & P-2011 & $43^{\circ} 57.613^{\prime} \mathrm{N}-05^{\circ} 45.771^{\prime} \mathrm{W}$ & 14.05 .2011 & 535 & 2 \\
\hline G06-A0511 & P-2011 & $44^{\circ} 01.030^{\prime} \mathrm{N}-05^{\circ} 27.579^{\prime} \mathrm{W}$ & 17.05 .2011 & 1,244 & 3 \\
\hline G07-A0511 & P-2011 & $43^{\circ} 58.801^{\prime} \mathrm{N}-05^{\circ} 28.763^{\prime} \mathrm{W}$ & 19.05 .2011 & 990 & $4+$ \\
\hline V02-A0511 & P-2011 & $43^{\circ} 54.982^{\prime} \mathrm{N}-06^{\circ} 14.752^{\prime} \mathrm{W}$ & 12.05 .2011 & 1,008 & 1 \\
\hline V03-A0511 & P-2011 & $43^{\circ} 57.710^{\prime} \mathrm{N}-06^{\circ} 28.048^{\prime} \mathrm{W}$ & 13.05 .2011 & 1,473 & 7 \\
\hline V07-A0511 & P-2011 & $43^{\circ} 58.752^{\prime} \mathrm{N}-05^{\circ} 28.606^{\prime} \mathrm{W}$ & 19.05 .2011 & 984 & 1 \\
\hline ROV6-A0412 & P-2012 & $43^{\circ} 58.877^{\prime} \mathrm{N}-05^{\circ} 49.523^{\prime} \mathrm{W}$ & 05.05 .2012 & 1,161 & $2+$ \\
\hline ROV8-A0912 & O-2012 & $43^{\circ} 51.0670^{\prime} \mathrm{N}-06^{\circ} 15.8423^{\prime} \mathrm{W}$ & 05.10 .2012 & 1,576 & 1 \\
\hline
\end{tabular}


Table 2 Scleractinians identified to species from the INDEMARES 2010-2012 expeditions to the Avilés Canyon System

\begin{tabular}{|c|c|c|c|c|c|}
\hline Species & A & B & $\mathrm{C}$ & $\mathrm{D}$ & $\mathrm{E}$ \\
\hline \multicolumn{6}{|l|}{$\begin{array}{l}\text { S.O. Fungiina Verrill, } \\
1865\end{array}$} \\
\hline \multicolumn{6}{|l|}{$\begin{array}{l}\text { F. Fungiacyathidae } \\
\text { Chevalier, } 1987\end{array}$} \\
\hline $\begin{array}{l}\text { Fungiacyathus fragilis } \\
\text { G.O Sars (1872) }\end{array}$ & $1744^{*}$ & - & - & $910-944$ & P-2010: DR21-A0410 (+) (1) \\
\hline \multicolumn{6}{|l|}{$\begin{array}{l}\text { S.O. Faviina Vaughan and } \\
\text { Wells, } 1943\end{array}$} \\
\hline \multicolumn{6}{|l|}{ F. Oculinidae Gray, 1847} \\
\hline $\begin{array}{l}\text { Madrepora oculata L. } \\
\text { (1758) }\end{array}$ & $342-1,660$ & $342-1,660$ & 1,318 & $200-1,710$ & $\begin{array}{l}\text { P-2010: DR03-A0410, DR04-A0410, DR05-A0410, DR06-A0410, } \\
\text { DR08-A0410, DR12-A0410, DR15-A0410 (+)-V-2010: DR06- } \\
\text { A0710, DR08-A0710, DR10-A0710, DR12-A0710, DR13- } \\
\text { A0710, DR15-A0710 (+), DR16-A0710-P-2011: DR03-A0511, } \\
\text { DR04-A0511, DR05-A0511, G01-A0511 (+), G04-A0511 (+), } \\
\text { G06-A0511, G07-A0511 (+)-P-2012: ROV6-A0412 (22) }\end{array}$ \\
\hline \multicolumn{6}{|l|}{$\begin{array}{l}\text { S.O. Caryophylliina } \\
\text { Vaughan and Wells, } \\
1943\end{array}$} \\
\hline \multicolumn{6}{|l|}{$\begin{array}{l}\text { F. Caryophylliidae Gray, } \\
1846\end{array}$} \\
\hline $\begin{array}{l}\text { Aulocyathus atlanticus } \\
\text { Zibrowius (1980) }\end{array}$ & 893 & 893 & - & $575-900$ & P-2010: DR03-A0410 (1) \\
\hline $\begin{array}{l}\text { Caryophyllia abyssorum } \\
\text { Duncan (1873) }\end{array}$ & 593-984* & - & - & $600-1,340$ & $\begin{array}{l}\text { P-2010: DR03-A0410 (+)—P-2011: DR04-A0511 (+), DR05- } \\
\text { A0511 (+), V07-A0511 (+) (4) }\end{array}$ \\
\hline $\begin{array}{l}\text { Caryophyllia atlantica } \\
\text { (Duncan 1873) }\end{array}$ & $1,533^{*}$ & 1,533 & - & $1,107-1,465$ & P-2010: DR24-A0410 (1) \\
\hline $\begin{array}{l}\text { Caryophyllia calveri } \\
\text { Duncan (1873) }\end{array}$ & $462-828$ & $700-776$ & 76 & $200-1,050$ & $\begin{array}{l}\text { P-2010: DR04-A0410, DR12-A0410 (+)-P-2011: DR03-A0511, } \\
\text { DR04-A0511 (+), DR06-A0511 (+) (5) }\end{array}$ \\
\hline $\begin{array}{l}\text { Caryophyllia sarsiae } \\
\text { Zibrowius (1974) }\end{array}$ & $700-1,533^{*}$ & $700-1,533$ & 833 & $880-1,100$ & $\begin{array}{l}\text { P-2010: DR03-A0410 (+), DR04-A0410, DR12-A0410 (+), DR24- } \\
\text { A0410-V-2010: DR08-A0710-P-2011: DR03-A0511, DR05- } \\
\text { A0511 (7) }\end{array}$ \\
\hline $\begin{array}{l}\text { Caryophyllia seguenzae } \\
\text { Duncan (1873) }\end{array}$ & 1,473 & 1,473 & - & $825-2,100$ & P-2011: V03-A0511 (1) \\
\hline $\begin{array}{l}\text { Caryophyllia smithii } \\
\text { Stokes and Broderip } \\
1828\end{array}$ & $128-893 *$ & 128 & - & $0-812$ & P-2010: DR03-A0410 (+)—V-2010: DR04-A0511 (2) \\
\hline $\begin{array}{l}\text { Deltocyathus eccentricus } \\
\text { Cairns (1979) }\end{array}$ & 1,473 & 1,473 & - & - & P-2011: V03-A0710 (1) \\
\hline $\begin{array}{l}\text { Deltocyathus moseleyi } \\
\text { Cairns (1979) }\end{array}$ & $593-908$ & $593-893$ & 300 & $532-1,372$ & $\begin{array}{l}\text { P-2010: DR03-A0410, DR04-A0410-P-2011: DR04-A0511, } \\
\text { DR05-A0511 (+) (4) }\end{array}$ \\
\hline $\begin{array}{l}\text { Desmophyllum cristagalli } \\
\text { Milne Edwards and } \\
\text { Haime (1848) }\end{array}$ & $551-2,291$ & $551-2,291$ & 1,740 & $73-2,310$ & $\begin{array}{l}\text { P-2010: DR03-A0410, DR04-A0410, DR07-A0410, DR08-A0410 } \\
\text { (+), DR11-A0410, DR12-A0410, DR18-A0410 (+), DR22- } \\
\text { A0410-V-2010: DR06-A0710, DR08-A0710, DR09-A0710 (+), } \\
\text { DR12-A0710, DR13-A0710, DR15-A0710 (+)-P-2011: DR03- } \\
\text { A0511, DR05-A0511, DR07-A0511, G07-A0511-P-2012: } \\
\text { ROV6-A0412 (19) }\end{array}$ \\
\hline Lophelia pertusa (L. 1758) & $342-1,473^{*}$ & $342-1,150$ & 808 & $260-1,420$ & $\begin{array}{l}\text { P-2010: DR03-A0410, DR04-A0410, DR05-A0410, DR06-A0410, } \\
\text { DR07-A0410, DR08-A0410, DR12-A0410-V-2010: DR01- } \\
\text { A0710 (+), DR06-A0710, DR08-A0710, DR10-A0710, DR12- } \\
\text { A0710, DR13-A0710, DR15-A0710 (+)-P-2011: DR03-A0511, } \\
\text { DR04-A0511 (+), DR05-A0511, DR07-A0511, G01-A0511 (+), } \\
\text { G02-A0511 (+), G03-A0511 (+), G04-A0511 (+), G07-A0511, } \\
\text { V03-A0511 (+) (24) }\end{array}$ \\
\hline $\begin{array}{l}\text { Paracyathus pulchellus } \\
\text { (Philippi 1842) }\end{array}$ & 128 & 128 & - & $73-425(?)$ & V-2010: DR04-A0710 (1) \\
\hline $\begin{array}{l}\text { Premocyathus cornuformis } \\
\text { (de Pourtalès 1868) }\end{array}$ & 1,008 & - & - & $700-2,360$ & P-2011: V02-A0511 (+) (1) \\
\hline $\begin{array}{l}\text { Solenosmilia variabilis } \\
\text { Duncan (1873) }\end{array}$ & $767-2,291^{*}$ & $767-2,291$ & 1,524 & $676-2,034$ & $\begin{array}{l}\text { P-2010: DR15-A0410, DR17-A0410, DR18-A0410, DR22-A0410, } \\
\text { DR23-A0410, DR24-A0410-P-2011: G03-A0511-O-2012: } \\
\text { ROV8-A0912 (8) }\end{array}$ \\
\hline
\end{tabular}


Table 2 continued

\begin{tabular}{|c|c|c|c|c|c|}
\hline Species & A & B & $\mathrm{C}$ & $\mathrm{D}$ & $\mathrm{E}$ \\
\hline $\begin{array}{l}\text { Stephanocyathus } \\
\text { moseleyanus (Sclater } \\
1886 \text { ) }\end{array}$ & $1,244-1,473$ & $1,244-1,473$ & 229 & $867-1,900$ & P-2011: G03-A0511, G06-A0511, V03-A0511 (3) \\
\hline $\begin{array}{l}\text { Stephanocyathus nobilis } \\
\text { (Moseley 1873) }\end{array}$ & $1,473-1,533^{*}$ & 1,473 & - & $1,490-2,170$ & P-2010: DR24-A0410 (+)—P-2011: V03-A0511 (2) \\
\hline $\begin{array}{l}\text { Vaughanella concinna } \\
\text { Gravier (1915) }\end{array}$ & $908-1,660$ & $908-1,660$ & 752 & $540-2,170$ & P-2010: DR15-A0410—P-2011: DR05-A0511 (2) \\
\hline \multicolumn{6}{|l|}{$\begin{array}{l}\text { F. Flabellidae Bourne, } \\
1905\end{array}$} \\
\hline $\begin{array}{l}\text { Flabellum alabastrum } \\
\text { Moseley } 1873\end{array}$ & $1,473-1,660$ & 1,660 & - & $800-2,177$ & P-2010: DR15-A0410—P-2011: V03-A0511 (+) (2) \\
\hline $\begin{array}{l}\text { Flabellum chunii Von } \\
\text { Marenzeller } 1904\end{array}$ & 1,473 & - & - & - & P-2011: V03-A0511 (+) (1) \\
\hline $\begin{array}{l}\text { Flabellum macandrewi } \\
\text { Gray } 1849\end{array}$ & 828 & 828 & - & $746-930$ & P-2010: DR12-A0410 (1) \\
\hline $\begin{array}{l}\text { Javania cailleti } \\
\text { (Duchassaing and } \\
\text { Michelotti 1864) }\end{array}$ & $1,476-2,291 *$ & $1,476-1,660$ & 815 & $915-2,150$ & $\begin{array}{l}\text { P-2010: DR15-A0410, DR16-A0410 (+), DR17-A0410, DR22- } \\
\text { A0410 (+) (4) }\end{array}$ \\
\hline $\begin{array}{l}\text { Monomyces pygmaea } \\
\text { (Risso 1826) }\end{array}$ & $55^{*}$ & 55 & - & $60-80$ & P-2011: DR08-A0511 (1) \\
\hline \multicolumn{6}{|l|}{$\begin{array}{l}\text { S.O. Dendrophylliina } \\
\text { Vaughan and Wells, } \\
1943\end{array}$} \\
\hline \multicolumn{6}{|l|}{$\begin{array}{l}\text { F. Dendrophylliidae Gray, } \\
1847\end{array}$} \\
\hline $\begin{array}{l}\text { Balanophyllia thalassae } \\
\text { Zibrowius (1980) }\end{array}$ & $462-767$ & $462-767$ & 305 & $380-1,150$ & $\begin{array}{l}\text { P-2010: DR04-A0410, DR18-A0410-P-2011: DR04-A0511, } \\
\text { DR06-A0511, DR07-A0511 (5) }\end{array}$ \\
\hline $\begin{array}{l}\text { Dendrophyllia cornigera } \\
\text { (Lamarck 1816) }\end{array}$ & $86-551$ & $103-893$ & 790 & $30-620$ & $\begin{array}{l}\text { V-2010: DR03-A0710-P-2011: DR01-A0511, DR07-A0511 (+), } \\
\text { DR09-A0511 (+) (4) }\end{array}$ \\
\hline $\begin{array}{l}\text { Eguchipsammia } \\
\text { cornucopia (de Pourtalès } \\
\text { 1871) }\end{array}$ & $593-767$ & - & - & $330-960$ & P-2010: DR18-A0410 (+)— P-2011: DR04-A0511 (+) (2) \\
\hline $\begin{array}{l}\text { Enallopsammia rostrata } \\
\text { (de Pourtalès 1878) }\end{array}$ & $990-2,291^{*}$ & $990-2,291$ & 1,301 & $915-1,980$ & $\begin{array}{l}\text { P-2010: DR22-A0410-V-2010: DR15-A0710—P-2011: G06- } \\
\text { A0511 (+), G07-A0511 (4) }\end{array}$ \\
\hline
\end{tabular}

(A) Depth interval (m) observed for each species. (B) Depth interval (m) observed for each species (only live specimens). (C) Difference (m) between the deepest and the shallow-most records (only live specimens). (D) Depth interval (m) previously known from the Bay of Biscay and nearby areas. (E) Stations (in brackets, total of stations for each species, dead and live specimens included). P-: Spring; V-: Summer; O-: Autumn. *) Live or dead specimens collected out of the depth range previously known in the Bay of Biscay and nearby areas. $(+)$ Only dead specimens collected at the station

\section{Results}

Order Scleractinia Bourne, 1900

Suborder Fungiina Verrill, 1865

Family Fungiacyathidae Chevalier, 1987

Fungiacyathus fragilis G.O. Sars 1872 (Fig. 2a)

Fungiacyathus fragilis G.O. Sars 1872: 58, pl. 5, figs. 24-32.-Zibrowius 1980: 23, pl. 5, figs. A-J.Altuna Prados 1994a: 455, pl. 10, fig. C, pl. 11, fig. C.Altuna Prados 1994b: 55 (annex, listed).-Altuna Prados 1994c: 78, fig. 1.—Altuna 1995: 86, fig. 1, 92 (tab. 1, listed).-Cairns and Chapman 2001: 36 (tab.1, listed).Molodtsova et al. 2008: 118, fig. 2C.- Reveillaud et al. 2008: 322 (tab. 1, listed), fig. 4.-Altuna 2010: 20 (listed)._Altuna 2012: 402 (tab. 2, listed), fig. 1.1.
Material examined P-2010: Stn. DR21-A0410, 1,744 m, 1 dead specimen.

Description Corallum unattached, discoid, fragile, very delicate, with $\mathrm{H}=5.0 \mathrm{~mm}$. Base almost flat, with a minute central pointed elevation. Wall very thin, costate, with poorly developed costae and sparse minute pointed granules. Costae slightly sinuous, ridged toward calicular edge. $\mathrm{C} 1-\mathrm{C} 3$ subequal and finely dentate extending to the center of base; C4-C5 poorly developed, mostly formed by a row of pointed granules. Calice slightly elongated with $\mathrm{GCD}=23.0 \mathrm{~mm}$ and $\mathrm{LCD}=19.0 \mathrm{~mm}$. Ninety-six septa arranged in five complete cycles and 6 systems, thin, delicate, fragile, with their faces spiny and connected laterally by thin plates. S1 only independent septa, reaching 


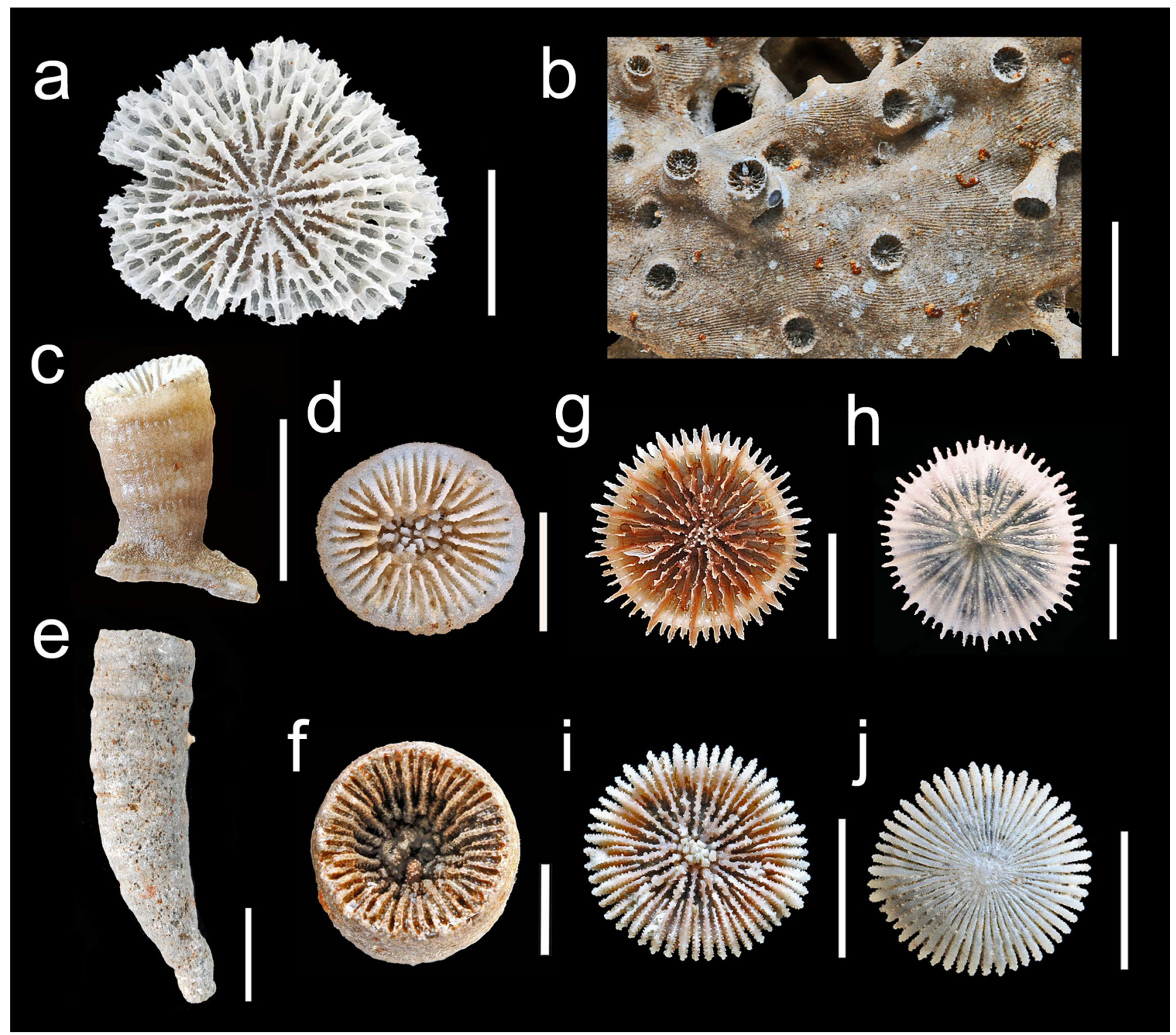

Fig. 2 Fungiacyathus fragilis G.O Sars 1872, Stn. DR21-A0410 (P2010). a Calicular view. Madrepora oculata L. 1758, Stn. DR15A0710 (V-2010). b Detail of a colony. Aulocyathus atlanticus Zibrowius 1980, Stn. DR03-A0410 (P-2010). c Corallum. d Calicular view of the same specimen. e Corallum. $\mathbf{f}$ Calicular view of the same specimen. Deltocyathus eccentricus Cairns 1979, Stn. V03-A0511 (P2011). g Calicular view. h Same specimen seen from below. Deltocyathus moseleyi Cairns 1979, Stn. DR04-A0511 (P-2011). i Calicular view. j Same specimen seen from below. Scale bar $\mathbf{a}-\mathbf{c}, \mathbf{e}$, $\mathbf{i}, \mathbf{j}=10 \mathrm{~mm} ; \mathbf{d}, \mathbf{f}-\mathbf{h}=5 \mathrm{~mm}$

fragilis is difficult to differentiate from $F$. marenzelleri (Vaughan 1906). According to Zibrowius (1980), we identify the specimen as $F$. fragilis due to a neat transverse undulation of S1 and S2, and a non-compact columella.

The record from the Avilés Canyon is the deepmost for the species in the Bay of Biscay and nearby areas although the specimen was dead. In being a well-preserved specimen despite its extreme fragility, it hardly was rolled from upper bathymetric levels and the species probably lives at this depth. Fungiacyathus fragilis was known from the Bay of Biscay only from Capbreton Canyon in a depth range of 
910-944 m (Altuna 1995). Depth in the Avilés Canyon is in accordance with the range of 200-2,200 $\mathrm{m}$ given by Cairns and Chapman (2001) for the eastern Atlantic.

This coral is distributed in the North Atlantic, but it is more abundant in the northeastern than in the northwestern Atlantic. In the eastern Atlantic, it occurs from almost the Arctic to the Cape Verde Islands, with records from Norway, west of Scotland, Celtic Sea, Mid-Atlantic Ridge, Bay of Biscay, Portugal, Madeira, and Azores (Gravier 1920; Zibrowius 1980; Altuna 1995; Molodtsova et al. 2008). Elsewhere it is known from New Zealand (Cairns 1995).

Suborder Faviina Vaughan and Wells, 1943

Family Oculinidae Gray, 1847

Madrepora oculata L. 1758 (Fig. 2b)

Madrepora oculata: Altuna 2012: 402 (tab. 2, listed).Altuna 2013: 103, tabs.1-3.

Material examined P-2010: Stn. DR03-A0410, 893 m, numerous fragments.-Stn. DR04-A0410, $700 \mathrm{~m}$, several fragments.-Stn. DR05-A0410, $688 \mathrm{~m}$, fragments.-Stn. DR06-A0410, $790 \mathrm{~m}$, several fragments.-Stn. DR08A0410, $844 \mathrm{~m}$, several colonies.-Stn. DR12-A0410, $828 \mathrm{~m}$, several fragments.-Stn. DR15-A0410, 1,660 m, small dead fragment. V-2010: Stn. DR06-A0710, 649 m, fragments.-Stn. DR08-A0710, 800 m, 1 fragment.-Stn. DR10-A0710, 342 m, small fragment.-Stn. DR12-A0710, $843 \mathrm{~m}$, small fragments.-Stn. DR13-A0710, $769 \mathrm{~m}$, small fragment.-Stn. DR15-A0710, 1,128 m, 1 big dead fragment.-Stn. DR16-A0710, 928 m, fragments. P-2011: Stn. DR03-A0511, $776 \mathrm{~m}$, several fragments.-Stn. DR04A0511, $593 \mathrm{~m}$, small fragments.-Stn. DR05-A0511, $908 \mathrm{~m}$, several fragments.-Stn. G01-A0511, $361 \mathrm{~m}, 1$ dead fragment.-Stn. G04-A0511, 535 m, 1 dead fragment growing on Lophelia pertusa.-Stn. G06-A0511, 1,244 m, 1 big colony.-Stn. G07-A0511, $990 \mathrm{~m}$, one small dead fragment. P-2012: Stn. ROV6-A0412, 1,161 m, 2 colonies, one growing on a dead antipatharian.

Remarks This coral has been collected from the study area by Álvarez Claudio (1994) and Altuna (2013). It cooccurs with Lophelia pertusa (L. 1758) in several stations of the Avilés Canyon System, particularly in the deepwater coral banks of the La Gaviera Canyon (see Sánchez et al. 2014). The material was collected at a depth interval of $342-1,660 \mathrm{~m}$, which is consistent with the interval of 200-1,710 m already known for this eurybathial species in the Bay of Biscay and nearby areas.

Madrepora oculata is a coral widely distributed (see Zibrowius 1980; Cairns 1982, 1991, 1994, 1995, 2004; Kitahara 2007) that was recently collected from the Avilés Canyon System, Le Danois Bank and the Galicia Bank (north and northwest Iberian bathyal, see Altuna 2013).
Suborder Caryophylliina Vaughan and Wells, 1943

Family Caryophylliidae Gray, 1846

Aulocyathus atlanticus Zibrowius 1980 (Fig. 2c-f)

Aulocyathus atlanticus Zibrowius 1980: 106, pl. 54, figs. A-P, pl. 55, figs. A-N.-Altuna 2012: 402 (tab. 2, listed), fig. 1.2.-Altuna 2013: 105, figs. 2A-A', B, tabs. 1-3 (listed).

Material examined P-2010: Stn. DR03-A0410, 893 m, one small specimen on coral debris, and a broken subfossil corallite.

Remarks The largest specimen is slightly curved, eroded, subfossil, pedicellated $(\mathrm{P}=3.0 \mathrm{~mm})$, with $\mathrm{H}=36.0 \mathrm{~mm}$, $\mathrm{GCD}=\mathrm{LCD}=10.0 \mathrm{~mm}$, and 42 septa. The calice in the smallest specimen collected are not perfectly round, with $\mathrm{GCD}=9.0 \mathrm{~mm}$ and $\mathrm{LCD}=8.0 \mathrm{~mm}$ for $\mathrm{H}=12.0 \mathrm{~mm}$ and 40 septa. In both specimens, the fossa is deep, and the septa bear numerous, small granules.

The specimens were collected in the study area associated with a deepwater coral bank framework and close to the lower depth level for the species in the Bay of Biscay (900 m, Zibrowius 1980).

Aulocyathus atlanticus is a rarely recorded bathyal coral distributed in the southern sector of the Bay of Biscay, Atlantic coast of the Iberian Peninsula, Azores, Madeira, and Morocco (see Zibrowius 1980). It was collected recently from the Galicia Bank (Altuna 2013). All the records given from the Bay of Biscay are from the southern sector (off Spain) further south than the $44^{\circ} 13^{\prime} \mathrm{N}$ parallel, in a bathymetric range of 575-900 $\mathrm{m}$.

Caryophyllia abyssorum Duncan 1873 (Fig. 3a, b)

Caryophyllia abyssorum Duncan 1873: 315, pl. 40, figs. 1-4.-Altuna 2012: 402 (tab. 2, listed), fig. 1.5.Altuna 2013: 107, figs. 2C-E, tabs. 1-3 (listed).

Material examined P-2010: Stn. DR03-A0410, 893 m, 3 dead corallites. P-2011: Stn. DR04-A0511, 593 m, a broken dead and worn specimen.-Stn. DR05-A0511, 908 m, 3 dead specimens, rather worn.-Stn. V07-A0511, $984 \mathrm{~m}$, a small dead specimen.

Remarks Specimen from Stn. V07-A0511 is the smallest collected in the expeditions. The corallum is slightly curved, with $\mathrm{H}=18.7 \mathrm{~mm}$ and a costate wall, with subequal costae. Calice is round, with $\mathrm{GCD}=\mathrm{LCD}=9.0 \mathrm{~mm}$. At this size, septa are already 40 arranged pentamerally, with a crown of 10P3. Fossa is shallow, containing a columella formed by three wellindividualized twisted rods.

Caryophyllia abyssorum is a bathyal coral that has been previously collected from the Avilés Canyon System by 


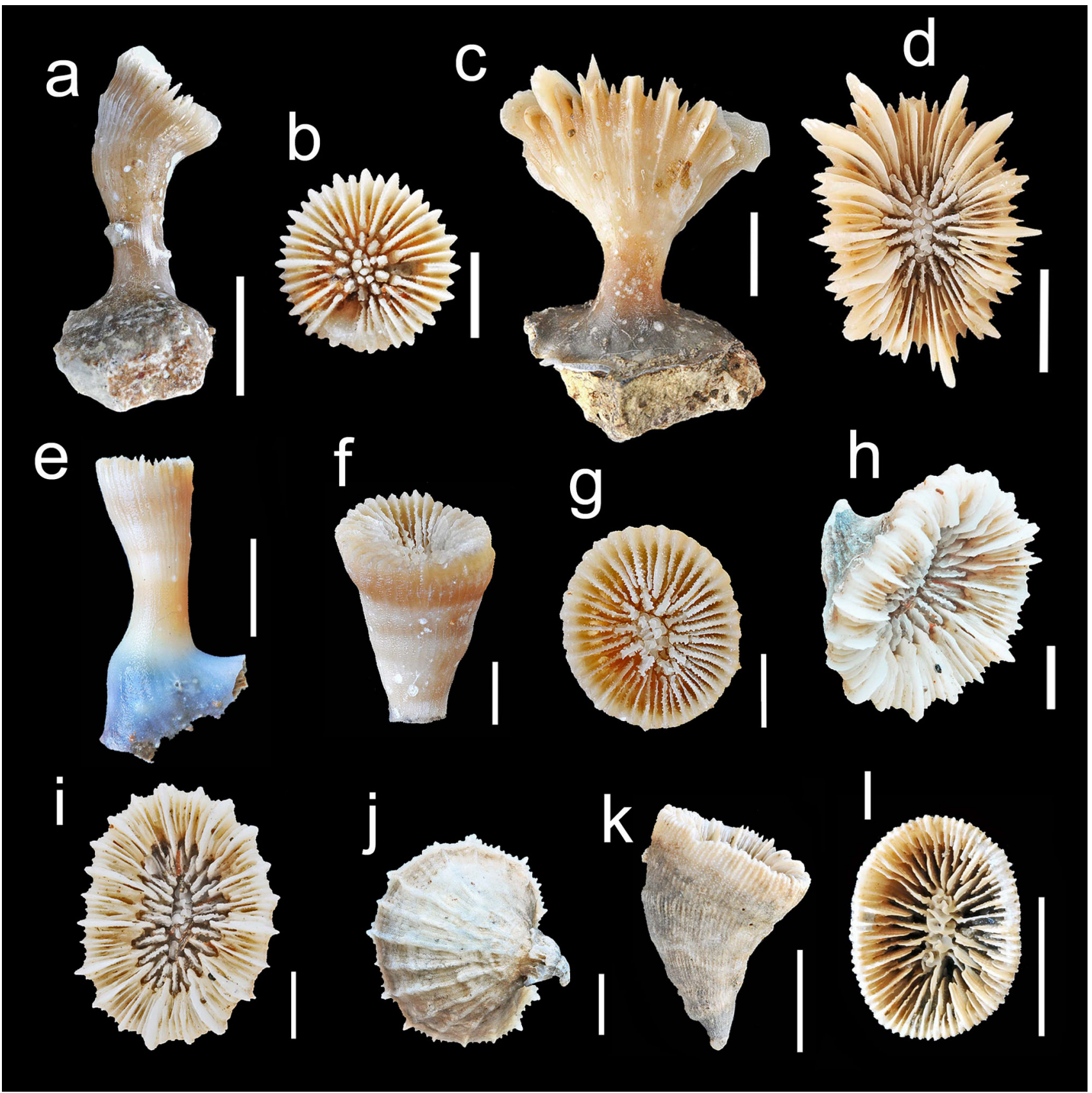

Fig. 3 Caryophyllia abyssorum Duncan 1873, Sn. DR03-A0410 (P2010). a Corallum. Note strong lateral curvature. b Same specimen in calicular view. Caryophyllia atlantica (Duncan 1873), Stn. DR24A0410 (P-2010). c Corallum. d Same specimen in calicular view. Caryophyllia calveri Duncan 1873. e Corallum, Stn. DR03-A0511 (P2011). f Corallum, Stn. DR04-A0410 (P-2010). g Same specimen in

Álvarez Claudio (1994). Most specimens examined herein were dead and rather worn. They were dredged from the La Gaviera Canyon at the east side of the Avilés Canyon System, within the depth range already known for the species in the Bay of Biscay and nearby areas according to a review of the literature $(600-1,340 \mathrm{~m})$. calicular view. Caryophyllia seguenzae Duncan 1873, Stn. V03A0511 (P-2011). h Corallum. i Same specimen in calicular view. j Same specimen seen from below. Caryophyllia smithii Stokes and Broderip, 1828, Stn. DR03-A0410 (P-2010). k Corallum. I Same specimen in calicular view. Scale bar a, c, d, h-l $=10 \mathrm{~mm}$; $\mathbf{b}=5 \mathrm{~mm} ; \mathbf{e}=8 \mathrm{~mm} ; \mathbf{f}, \mathbf{g}=5 \mathrm{~mm}$

According to Zibrowius (1980), this species is known in the eastern Atlantic between the Celtic Sea, the Azores archipelago and the Western Sahara. In the Bay of Biscay, it has been recorded from the southern and northern sectors. It was recently collected from Le Danois Bank and redescribed by Altuna (2013). 
Caryophyllia atlantica (Duncan 1873) (Fig. 3c, d)

Bathycyathus atlanticus Duncan 1873: 318, pl. 48, figs. 1-2.

Caryophyllia atlantica: Zibrowius 1980: 56, pl. 20, figs. A-K.-Cairns and Chapman 2001: 34 (tab. 1, listed).Brito and Ocaña 2004: 376.-Reveillaud et al. 2008: 322 (tab. 1, listed), fig. 4.-Altuna 2010: 21 (listed).Kitahara et al. 2010: 97, figs. 11, 16.-Altuna 2012: 402 (tab. 2, listed), fig. 1.6.

Caryophyllia (C.) atlantica: Cairns 1995: 47, pl. 8, figs. d-e.

Material examined P-2010: Stn. DR24-A0410, 1,533 m, 3 specimens on coral debris and stones, 2 of them dead.

Description Corallum solitary, 31.0-33.0 mm in height, attached, pedicellate, turbinate, moderately compressed. Pedicel straight or slightly curved $(\mathrm{PD}=5.5-7.0 \mathrm{~mm})$, extending into a thin and well-developed basal plate. Wall glossy, distally costate. Costae subequal in width and finely granulated with nonaligned granules, those of dominant septa being prominent, subacute. Calice strongly flared, elliptical, with 54-60 septa arranged in three size classes and 13-15 sectors $[\mathrm{GCD}=33.0 \mathrm{~mm}, \mathrm{LCD}=23.0 \mathrm{~mm}$, $\mathrm{GCD} / \mathrm{LCD}=1.43$, PD: $\mathrm{GCD}=0.21$ (60 septa, 15P2); $\mathrm{GCD}=30.0 \mathrm{~mm}, \mathrm{LCD}=21.0 \mathrm{~mm}, \mathrm{GCD} / \mathrm{LCD}=1.43$, PD: $\mathrm{GCD}=0.18$ (54 septa, 14P2)]. S1 dominant, very exsert, followed by $\mathrm{S} 3$ in their exsert projection; S2 less exsert. S1 larger than S2, and these, thinner than S3. S3 extending farther toward the columella than S2. Upper septal margins smooth, with their septal faces finely granulated with small, pointed granules. Inner edges straight, descending vertically into the fossa, particularly in $\mathrm{S} 1$. Palar crown well defined before $\mathrm{S} 2$, formed by 14-15P2. Pali well developed, thicker than S2, with inner edges sinuous and granules that are much larger than those of the septa. Fossa shallow, containing a columella below the calicular margin and the palar crown levels. Columella elongate, formed by 6-8 twisted ribbons, enclosed by the palar crown. Corallum light brown.

Remarks The specimens are in all coincident with material described by Zibrowius (1980, pl. 20) from the northeastern Atlantic. However, the specimens here studied are considerably more flared distally (PD: GCD $=0.18-0.21)$ than coralla depicted by Cairns (1995) and Kitahara et al. (2010).

Caryophyllia atlantica is rarely recorded in the Bay of Biscay and nearby areas, with previous data of Marion (1906, off Spain) and Zibrowius (1980). Depth in the Avilés Canyon System is consistent with the range of 1,100-2,165 m given by Cairns and Chapman (2001) for this eurybathial species in the eastern Atlantic, but it occurs at a deeper depth $(1,533 \mathrm{~m})$ than previous data from the Bay of Biscay and nearby areas after a review of the literature (1,107-1,465 m). This species is widely distributed, with records from the eastern Atlantic, the Mediterranean Sea, and the Pacific Ocean, in a considerable depth range (Zibrowius 1980; Cairns 1995; Kitahara et al. 2010).

\section{Caryophyllia calveri Duncan 1873 (Fig. 3e-g)}

Caryophyllia calveri Duncan 1873: 316.-Altuna 2012:

402 (tab. 2, listed), fig. 1.3.-Altuna 2013: 107, figs. 2F-H, M, tabs. 1-3 (listed).

Material examined P-2010: Stn. DR04-A0410, 700 m, 3 corallites, 2 dead, one of them growing on coral debris.Stn. DR12-A0410, 828 m, 1 dead corallite on coral debris. P-2011: Stn. DR03-A0511, 776 m, 3 small corallites, one dead, on coral debris.-Stn. DR04-A0511, 593 m, 1 dead, worn specimen.-Stn. DR06-A0511, 462 m, 1 dead corallite on Balanophyllia thalassae Zibrowius 1980.

Remarks Specimen of Stn. DR06-A0511 is small, curved, and the calice is slightly polygonal in calicular view, with 48 septa hexamerally arranged (S1-S4) and 12P3. S1 and $\mathrm{S} 2$ are subequal, and S4 extends farther toward the columella than S3. S1 and S2 are moderately and equally exsert and are followed by $\mathrm{S} 4$ in their exsert projection. Specimen from Stn. DR04 has 40 septa arranged pentamerally with $10 \mathrm{P} 3$.

According to the results from the IEO expeditions (see also Altuna 2013), C. calveri is collected frequently in the north and northwest (Galicia Bank) Iberian bathyal using white coral as substrate, although it never occurs in abundance. It was collected in the canyon at a depth that is consistent with the range known for the species in the Bay of Biscay and nearby areas after a review of the literature (200-1,050 m).

Caryophyllia calveri is a coral widely distributed in the Mediterranean Sea and the northeast Atlantic. It has been recently redescribed from the Avilés Canyon System, Le Danois Bank and the Galicia Bank of north and northwest Spain (Altuna 2013).

Caryophyllia sarsiae Zibrowius 1974 (Fig. 4a-n)

Caryophyllia sarsiae Zibrowius 1974: 779, pl. 3, figs. A-F._Altuna 2012: 402 (tab. 2, listed), fig. 1.4.Altuna 2013: 108, figs. 2I-L, tabs. 1-3 (listed).

Material examined P-2010: Stn. DR03-A0410, 893 m, 3 dead specimens growing on coral debris.-Stn. DR04A0410, 700 m, 2 specimens, 1 dead.-Stn. DR12-A0410, $828 \mathrm{~m}, 2$ dead specimens on coral and shell debris.-Stn. DR24-A0410, 1,533 m, 1 specimen. V-2010: Stn. DR08A0710, 800 m, 2 specimens. P-2011: Stn. DR03-A0511, $776 \mathrm{~m}, 3$ specimens, 2 of them worn and dead on coral 
debris and one corroded by Lumbrineris.-Stn. DR05A0511, 908 m, 2 live specimens corroded by Lumbrineris, 3 dead specimens, worn, subfossil.

Remarks The external shape of the corallum in the material from the canyon is highly variable (Fig. $4 a-n$ ). Most specimens are straight and turbinate, although others can be also curved. The calice is round in oral view. Septa are always 48 in the material examined, hexamerally arranged in four cycles S1-S4, with S1-2 > S3 $>$ S4, and $12 \mathrm{P} 3$. S1 and $\mathrm{S} 2$ extend similarly toward columella reaching the level of the middle of the pali, slightly more than S3, and these, more than S4. S1-S2 are normally very exsert and more than S3. S4 follows slightly S1-S2 in their exsert projection and remains at the same level than $\mathrm{S} 3$.

In the study area, $C$. sarsiae is frequently associated with the deepwater white coral banks framework and uses bank builders as substrate. This may be one of the reasons to explain the variability in the morphology of the corallum, whose shape could be conditioned by the growth of nearby branches of the colonial species.

Caryophyllia sarsiae, C. abyssorum and C. calveri can be sometimes difficult to distinguish, in part due to variability in the symmetry of $C$. abyssorum and $C$. calveri (pentameral or hexameral) and in the variability of the habitus of C. sarsiae. In C. sarsiae and C. abyssorum, S3 are wider than $\mathrm{S} 4$ and extend similarly to columella. However, in the former, S3 and S4 are equally exsert, whether in C. abyssorum S3 are more exsert than S4.

This coral was previously known in a range of $751-1,100 \mathrm{~m}$ depth in the Bay of Biscay and nearby areas (Zibrowius 1974, 1980; Zibrowius et al. 1975; Altuna 1995, 2013). Hence, the record from Stn. DR04-A0410 $(700 \mathrm{~m})$ is the shallowest given from this area, and that from Stn. DR24-A0410 (1,533 m), the deepmost. New depth data are consistent with the range of 500-2,200 m given by Cairns and Chapman (2001) for the species in the eastern Atlantic.

This species is distributed worldwide, with several records from the Mediterranean Sea and the northeastern Atlantic. It is known from the Celtic Sea, Azores archipelago, and Madeira (Zibrowius 1980) and has been also recorded from Bermuda, South Africa, and Australia (see Cairns and Parker 1992; Cairns 2000). It was recently collected from Le Danois Bank (Bay of Biscay) and redescribed by Altuna (2013).

Caryophyllia seguenzae Duncan 1873 (Fig. 3h-j)

Caryophyllia seguenzae Duncan 1873: 314, pl. 44, figs. 4-6.-Altuna 2012: 402 (tab. 2, listed).-Altuna 2013: 109, figs. $2 \mathrm{~N}-\mathrm{O}$, tabs. 1-3 (listed).
Fig. 4 Caryophyllia sarsiae Zibrowius 1974. a Corallum, Stn. DR03A0511 (P-2011). b Same specimen in calicular view. c Corallum, Stn. DR03-A0511 (P-2011). d Corallum, Stn. DR12-A0410 (P-2010). e Corallum, Stn. DR03-A0410 (P-2010). f Same specimen in calicular view. g Corallum, Stn. DR05-A0511 (P-2011). h Corallum, Stn. DR03-A0410 (P-2010). i Corallum, Stn. DR04-A0410 (P-2010). j Same specimen in calicular view. k Corallum, Stn. DR08-A0710 (V-2010). I Same specimen in calicular view. m Corallum, Stn. DR08-A0710 (V-2010). n Corallum, Stn. DR12-A0410 (P-2010). Scale bar a, e, $\mathbf{k}=15 \mathrm{~mm} ; \mathbf{b}, \mathbf{d}, \mathbf{f}-\mathbf{j}, \mathbf{l}-\mathbf{n}=10 \mathrm{~mm} ; \mathbf{c}=20 \mathrm{~mm}$

Material examined P-2011: Stn. V03-A0511, 1,473 m, 6 specimens, 3 of them dead.

Remarks This species has been recently redescribed from Le Danois Bank in the Bay of Biscay (Altuna 2013). The material collected from the canyon fully agrees with specimens studied by this author. The largest specimen collected is $34.0 \mathrm{~mm}$ in GCD, $26.0 \mathrm{~mm}$ in LCD, and $24.0 \mathrm{~mm}$ in height. As usual, coralla are unattached, proximally curved, and have a small pointed base.

The depth of collection (live specimens) is in accordance with previous data from the Bay of Biscay (see $\mathrm{Zi}-$ browius 1980).

Caryophyllia seguenzae is a soft-bottom coral that may be abundant in the Bay of Biscay (Roule 1896; Marion 1906; Zibrowius 1980; Altuna Prados 1994a; Altuna 1995, 2013). It is common in the Capbreton Canyon off the Basque coast (Altuna 1995), but has not been recorded previously from the Avilés Canyon System. Elsewhere, it is known from western Ireland to the Guinea Gulf, including the Canary Islands and the Cape Verde archipelago, but it is unknown from the Mediterranean Sea (Zibrowius 1980).

Caryophyllia smithii Stokes and Broderip, 1828 (Fig. 3k, 1)

Caryophyllia smithii: Zibrowius 1980: 46, pl. 16, figs. A-K, pl. 17, figs. A-L.-Monteiro Marques and Andrade 1981: 88 (listed).—Aguirrezabalaga et al. 1984: 93.Zibrowius 1985: 314 (tab. 2, listed), 316.-Altuna and García Carrascosa 1990: 56 (listed)._-Ramil Blanco and Fernández Pulpeiro 1990: 26.-Á́lvarez Claudio 1993: 417 (listed).-Rallo et al. 1993: 74 (tab. 2, listed).Altuna Prados 1994a: 464.-Altuna Prados 1994b: 55 (annex, listed)._Altuna Prados 1994c: 70, fig. 1.Álvarez Claudio 1994: 464.-Altuna 1995: 92 (tab. 1, listed).-Cairns and Chapman 2001: 35 (tab. 1, listed).-Serrano et al. 2006: 158 (listed, app. I).OSPAR 2008: 38 (listed).-—Reveillaud et al. 2008: 322 (tab. 1, listed), fig. 4.-Sánchez et al. 2008: 70 (fig. 5), 74 (listed, tab. 3), 84 (appendix A, listed).-Sánchez et al. 2009: 1180 (tab. 2, listed).-Altuna 2010: 21 (listed).-Louzao et al. 2010: tab. S1 (listed).--Serrano 


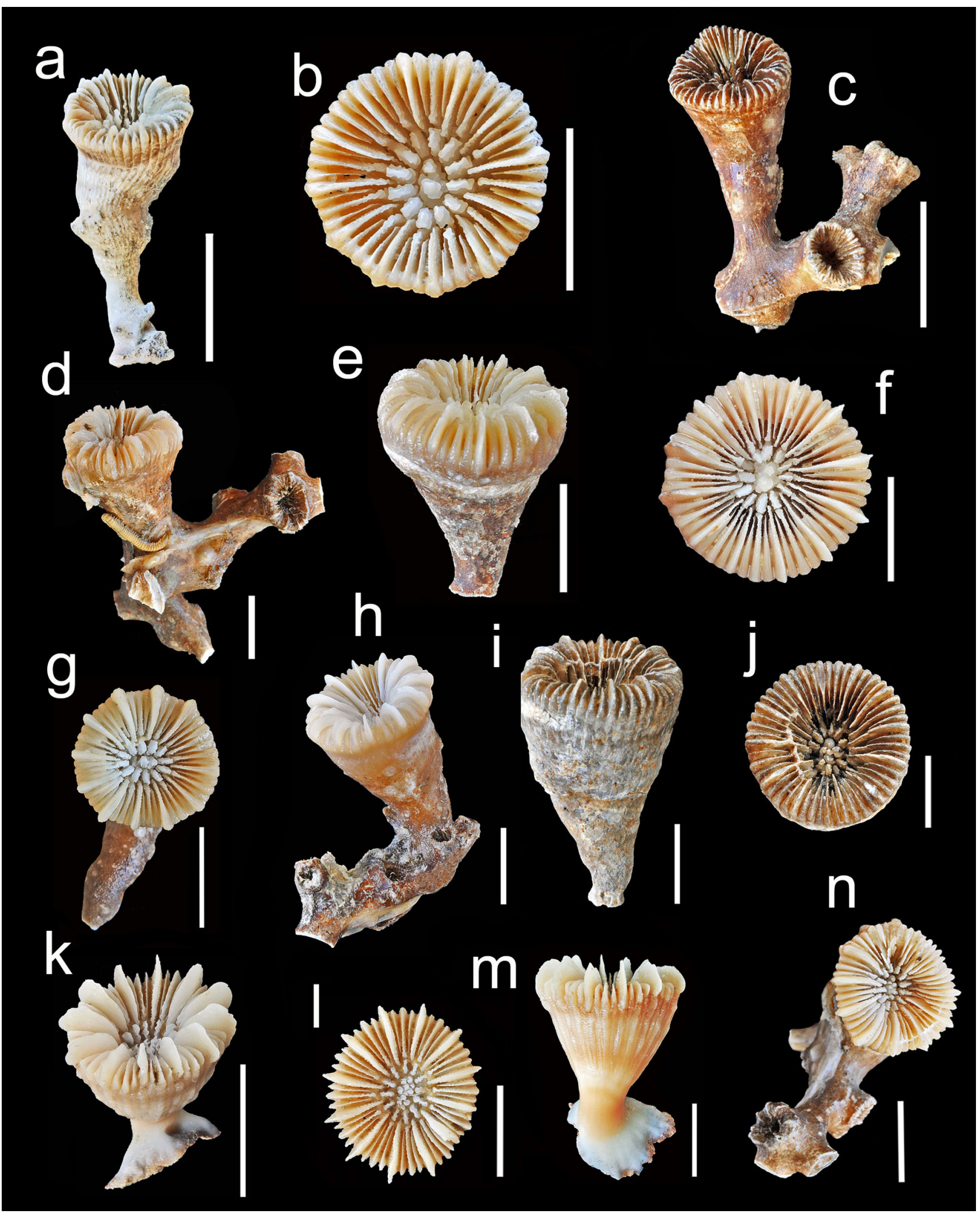


et al. 2011: 429 (tab. 2, listed).-Altuna 2012: 402 (tab. 2, listed).-Altuna 2013: 105 (tab. 2, listed).

Caryophyllia smithi: Isasi and Saiz 1986: 72 (listed).Sorbe 1990: 130 (tab. 6, listed).-Paulmier 1997: 13, pl. 8, figs. 3-4.

Material examined P-2010: Stn. DR03-A0410, $893 \mathrm{~m}, 1$ dead specimen, eroded. V-2010: Stn. DR04-A0710, 128 m, 2 small specimens.

Remarks The material consists in a dead specimen of the soft-bottom morph and two small corallites of the hardbottom morph. The former is unattached, trochoid, slightly curved in the plane of GCD and compressed laterally $(\mathrm{H}=19.0 \mathrm{~mm} ; \mathrm{GCD}=16.0 \mathrm{~mm} ; \mathrm{LCD}=12.0 \mathrm{~mm})$. It has 76 septa, but the number of pali cannot be ascertained with certitude due to an unsatisfactory condition of the specimen. The wall is fully costate. The columella is elongated, located in the center of a moderately deep fossa, and is formed by a few twisted ribbons.

The corallites from Stn. DR04-A0710 are subcylindric, with $\mathrm{H}=6.0 \mathrm{~mm}, \mathrm{GCD}=7.0 \mathrm{~mm}, \mathrm{LCD}=5.7 \mathrm{~mm}$, and $\mathrm{H}=8.0 \mathrm{~mm}, \mathrm{GCD}=6.6 \mathrm{~mm}, \mathrm{LCD}=5.0 \mathrm{~mm}$. The latter specimen has 46 septa hexamerally arranged, with 10 pali, from which $2 \mathrm{P} 2$ and $8 \mathrm{P} 3$. $\mathrm{P} 2$ are rather smaller than $\mathrm{P} 3$. Although all the systems are not complete in this specimen, with some S4 lacking, 2S5 start to develop in one of the systems. The fossa is moderately shallow, containing a columella that is slightly elongated and formed by three twisted ribbons.

This species has been occasionally cited in papers dealing with the littoral and bathyal ecology of the southern sector of the Bay of Biscay (see list of citations), but very likely several of these records refer to other species. Probably, littoral records of $C$. smithii from the southeast of the bay correspond to Caryophyllia inornata (Duncan 1878) (see Altuna Prados, 1994a, c). In the southern sector of the bay, C. smithii (unattached specimens) is locally abundant in soft bottoms of fine, medium-sized and coarse sand and gravel of the shelf, but is rarely recorded at both bathyal depths and hard bottoms of the littoral.

The specimen of the soft-bottom morph was collected at a depth of $893 \mathrm{~m}$. This is the deepest record in the Bay of Biscay and nearby seas. Depth is also deeper than the range of $40-400 \mathrm{~m}$ given by Cairns (2010) for the species. However, in being a dead specimen, it could have been rolled from upper bathymetric levels.

The distribution of $C$. smithii was traced by Zibrowius (1980). It is a coral known in the eastern Atlantic from Norway to Congo, including records from the Mediterranean Sea, and the archipelagos of Azores, Madeira, and the Canary Islands. We refer to this author for a full list of records.
Deltocyathus eccentricus Cairns 1979 (Fig. 2g, h) Deltocyathus eccentricus Cairns, 1979: 98, pl. 18, figs. 8-11.-Altuna 2012: 402 (tab. 2, listed), fig. 1.8.-Altuna 2013: 110, figs. 3A-B, tabs. 1-3 (listed).

Material examined P-2011: Stn. V03-A0511, 1,473 m, 2 small specimens, 1 dead.

Description Corallum unattached and solitary $(\mathrm{H}=$ $3.0 \mathrm{~mm}, \mathrm{GCD}=\mathrm{LCD}=10.0 \mathrm{~mm} ; \mathrm{H}=2.8 \mathrm{~mm}, \mathrm{GCD}=$ $\mathrm{LCD}=9.5 \mathrm{~mm}$ ), light, fragile, patellate. Color whitish to light brown. Wall thin, with a thickened calicular edge. Base slightly convex with a minute central pointed elevation, entirely costate. Costae thin and finely granular, arranged according to the formula $\mathrm{C} 1-2>\mathrm{C} 3>\mathrm{C} 4$ with $\mathrm{C} 1-\mathrm{C} 2$ ridged and reaching epicenter of base. Calices slightly irregular in calicular view, with 56 septa hexamerally arranged in 6 systems and 4 complete cycles S1-S4, with some additional S2-S4; S1 and S2 are almost equally exsert with S3 and S4 progressively less exsert. S1 slightly larger than S2, independent, and reaching the columella through their pali; S2 shorter than $\mathrm{S} 1$, also reaching the columella by their pali, and larger than S3; S3 larger than S4 and joining S2 close to the columella forming deltas; $\mathrm{S} 4$ rudimentary, scarcely extending toward the columella, joining S3 deep in the fossa. Septa with their axial edges slightly sinuous and smooth faces. Pali in three crowns P1-P3 set apart from septa by a deep notch, narrow, sinuous, with scarce small pointed granules. P1 are the nearest to columella, then P2, and finally P3. Fossa shallow to moderately deep, with columella below pali level formed by a few small rods, and several fused elements in one of the specimens.

Remarks Both specimens are very fragile young coralla with 56 septa, due to extra septa S2-S4 of an imperfect system, and not to an incomplete cycle S5.

Depth of Stn V03-A0511 is remarkable $(1,473 \mathrm{~m})$, as Cairns and Chapman (2001) and Kitahara and Cairns (2009) give a depth range of 300-1,000 $\mathrm{m}$ for the species in the eastern Atlantic.

Deltocyathus eccentricus is an amphi-Atlantic coral rarely recorded in the northeastern Atlantic and distributed in Azores, the Gorringe Bank, and the Cape Verde Islands (Zibrowius 1980). It has been recently collected from the Galicia Bank, where it can be very abundant; this population was the northernmost known so far (Altuna 2013). The species is here first recorded from the Bay of Biscay.

Deltocyathus moseleyi Cairns 1979 (Fig. 2i, j)

Deltocyathus moseleyi Cairns 1979: 100, pl. 18, figs. 13.-Altuna 2012: 402 (tab. 2, listed), fig. 1.9.-Altuna 2013: 111, figs. 3C-F, tabs. 1-3 (listed). 
Material examined P-2010: Stn. DR03-A0410, 893 m, 3 specimens and some fragments, 2 dead and eroded.-Stn. DR04-A0410, 700 m, 1 specimen. P-2011: Stn. DR04A0511, 593 m, 7 specimens, 5 dead.-Stn. DR05-A0511, 908 m, 24 dead specimens, much eroded.

Remarks All the specimens collected have almost round calices $(\mathrm{GCD}=\mathrm{LCD})$, with the biggest one being $16.0 \mathrm{~mm}$ wide in GCD, for a height of $5.0 \mathrm{~mm}$ (Stn. DR04, P-2011). The smallest was collected at the same station and has a $\mathrm{GCD}=\mathrm{LCD}=9.0 \mathrm{~mm}$, with $\mathrm{H}=5.0 \mathrm{~mm}$. Height is variable in coralla having the same GCD, with some specimens showing a more pronounced vertical growth.

Specimens were collected in a depth range of 615-932 $\mathrm{m}$ that fully agrees with previous depth data for the species in the Bay of Biscay and nearby areas after a review of the literature (532-1,372 m).

Deltocyathus moseleyi is widely distributed in the northeastern Atlantic in an area between the Celtic Sea, Azores, and Madeira and also in the northeastern Atlantic (Cairns 1979; Zibrowius 1980). It has been frequently collected in the IEO surveys off north and northwest Spain and is probably common in the bathyal of the southern sector of the Bay of Biscay (see Altuna 2013). However, and on the contrary to D. eccentricus, it hardly occurs in abundance in the IEO study areas (Le Danois Bank, Avilés Canyon System, Galicia Bank), and specimens are frequently dead and eroded.

Desmophyllum cristagalli Milne Edwards and Haime 1848 (Fig. 5a-d)

Desmophyllum cristagalli: Altuna 2012: 402 (tab. 2, listed), fig. 1.12.-Altuna 2013: 113, tabs. 1-3 (listed).

Material examined P-2010: Stn. DR03-A0410, 893 m, 1 broken specimen, substrate unknown, and 1 dead and eroded on coral debris.-Stn. DR04-A0410, $700 \mathrm{~m}, 5$ small specimens, 2 dead.-Stn. DR07-A0410, 1,150 m, 1 small specimen.-Stn. DR08-A0410, $844 \mathrm{~m}, 3$ dead specimens, eroded, on coral debris.-Stn. DR11-A0410, 636 m, 4 specimens, 1 dead.-Stn. DR12-A0410, 828 m, 7 specimens, 5 dead, 1 on coral debris.-Stn. DR18-A0410, $767 \mathrm{~m}, 1$ eroded dead specimen on coral debris.-Stn. DR22-A0410, 2,291 m, several specimens. V-2010: Stn. DR06-A0710, 649 m, 1 big specimen on coral debris.Stn. DR08-A0710, $800 \mathrm{~m}$, several big specimens on coral debris.-Stn. DR09-A0710, $626 \mathrm{~m}, 1$ dead specimen on coral branch, broken.-Stn. DR12-A0710, 843 m, 1 specimen.-Stn. DR13-A0710, 769 m, 5 specimens on coral debris and Madrepora oculata, 2 dead.-Stn. DR15A0710, 1,228 m, 4 dead specimens on dead M. oculata. P-2011: Stn. DR03-A0511, 776 m, 10 specimens, some dead, on coral debris.-Stn. DR05-A0511, $908 \mathrm{~m}, 20$ corallites and fragments, 15 dead and subfossil, much worn, some on M. oculata.-Stn. DR07-A0511, $551 \mathrm{~m}, 4$ specimens on coral debris.-Stn. G07-A0511, 990 m, 3 corallites on Lophelia pertusa. P-2012: Stn. ROV6-A0412, 1,161 m, 6 small specimens, 3 dead.

Remarks A discussion on the nomenclature of this species was provided by Altuna (2013). Desmophyllum cristagalli is abundant in the canyon and in the Bay of Biscay and nearby areas. In the canyon, it has been collected in a depth range of 551-2,291 m, which fully agrees with the depth range of $73-2,310 \mathrm{~m}$ known for this eurybathic species in the Bay of Biscay and nearby areas.

It is a coral morphologically very variable, and sometimes large sized. One specimen from Stn. DR22-A0410 (P-2010), with highly exsert septa, certainly reminds $J a$ vania cailleti forma nobile (see Cairns 2000, fig. 168) but the arrangement of septa leaves no doubt about its identification. This coral is frequently associated with the deepwater coral bank framework of the La Gaviera Canyon within the Avilés Canyon System (for instance, V-2010: DR13-A0710, DR15-A0710; P-2011: DR05-A0511, all specimens growing on $M$. oculata) and uses colonial bank builder corals as substrate. This could be one of the reasons explaining the variability of the corallum, whose morphology could be conditioned by the growth of nearby branches of the colonial species. Desmophyllum cristagalli frequently uses other coralla of the same species as substrate (autoepizoism) forming small clumps (Stn. DR22A0410, Fig. 5d).

This is a cosmopolitan species widely distributed in the Mediterranean Sea and the northeast Atlantic (Zibrowius 1980), and very abundant in the Bay of Biscay.

Lophelia pertusa (L. 1758) (Fig. 5e)

Lophelia pertusa: Altuna 2012: 402 (tab. 2, listed).Altuna 2013: 113, tabs. 1-3 (listed).

Material examined P-2010: Stn. DR03-A0410, 893 m, small fragments.-Stn. DR04-A0410, $700 \mathrm{~m}$, several fragments, some dead.-Stn. DR05-A0410, $688 \mathrm{~m}$, several fragments.-Stn. DR06-A0410, $790 \mathrm{~m}$, several fragments.-Stn. DR07-A0410, 1,150 m, some fragments.Stn. DR08-A0410, 844 m, small colonies.-Stn. DR12A0410, $828 \mathrm{~m}$, small fragments. V-2010: Stn. DR01A0710, $810 \mathrm{~m}$, some dead fragments, eroded.-Stn. DR06A0710, 649 m, small fragments, some dead.-Stn. DR08A0710, $800 \mathrm{~m}$, small fragment.-Stn. DR10-A0710, $342 \mathrm{~m}, 1$ small fragment.-Stn. DR12-A0710, $843 \mathrm{~m}$, small fragments, some dead.-Stn. DR13-A0710, 769 m, 1 colony.-Stn. DR15-A0710, 1,228 m, big fragment, dead. P-2011: Stn. DR03-A0511, $776 \mathrm{~m}$, several colonies and fragments, some dead.-Stn. DR04-A0511, 593 m, small 


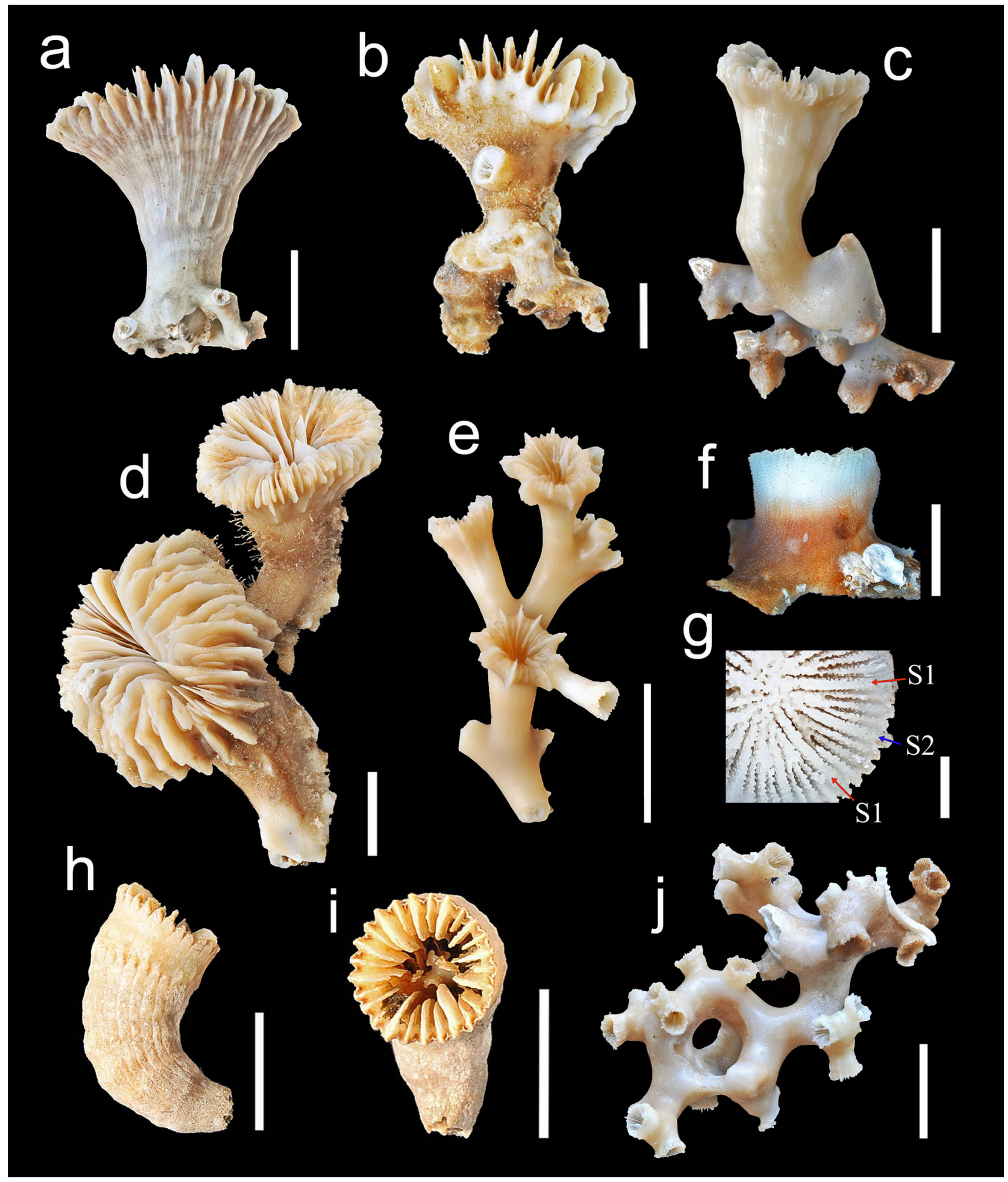

Fig. 5 Desmophyllum cristagalli Milne Edwards and Haime 1848. a Corallum, Stn. DR03-A0511 (P-2011). b, c, d Coralla, Stn. DR22A0410 (P-2010); note the variability occurring in specimens from a same station and the great development of the basal plate in c. Lophelia pertusa (L. 1758), Stn. DR04-A0410 (P-2010). e Fragment of a colony. Paracyathus pulchellus (Philippi 1842), Stn. DR04-
A0710 (V-2010). f Corallum, side view. g Same specimen, detail of calice to show deltas. Premocyathus cornuformis (de Pourtalès 1868), Stn. V02-A0511 (P-2011). h Corallum. i Same specimen in calicular view. Solenosmilia variabilis Duncan 1873, Stn. G03-A0511 (P2011). j Fragment of a colony. Scale bar $\mathbf{a}-\mathbf{c}, \mathbf{e}, \mathbf{j}=15 \mathrm{~mm}$; $\mathbf{d}=20 \mathrm{~mm} ; \mathbf{h}, \mathbf{i}=8 \mathrm{~mm} ; \mathbf{f}=5 \mathrm{~mm} ; \mathbf{g}=2 \mathrm{~mm}$ 
fragment, dead and eroded.-Stn. DR05-A0511, $908 \mathrm{~m}$, small colonies and fragments, some dead, on M. oculata.Stn. DR07-A0511, $551 \mathrm{~m}$, small fragments.-Stn. G01A0511, $361 \mathrm{~m}$, small dead fragments.-Stn. G02-A0511, $1,051 \mathrm{~m}$, small fragments, dead.-Stn. G03-A0511, 1,464 m, small fragment, dead, eroded.-Stn. G04-A0511, $535 \mathrm{~m}$, small dead fragment on M. oculata.-Stn. G07A0511, 990 m, several fragments, some dead.-Stn. V03A0511, 1,473 m, 1 dead polyp, eroded, with an incipient ramification and a small subfossil fragment, much eroded (doubtful identification).

Remarks Lophelia pertusa is an abundant species in the Bay of Biscay, in the Avilés Canyon System and in the Galicia Bank (Altuna 2013). It commonly co-occurs with M. oculata, particularly so in the deepwater coral banks framework of the La Gaviera Canyon as a bank builder species (see remarks in that species). Depth of Stn. V03A0511 is deeper than the range of 260-1,420 m known for the species in the Bay of Biscay and nearby areas, but only a small dead fragment was collected that could have been transported from a shallower bathymetric level.

This is a coral distributed in the Atlantic and the Mediterranean Sea (Zibrowius 1980) that has been also recorded in the Pacific and Indian oceans (Cairns 1994).

Paracyathus pulchellus (Philippi 1842) (Fig. 5f, g)

Paracyathus pulchellus: Zibrowius 1980: 90, pl. 44, figs. A-K, pl. 45, figs. A-L.-Aguirrezabalaga et al. 1988: 237.-Altuna and García Carrascosa 1990: 56 (listed).Álvarez Claudio 1993: 417 (listed)._Altuna Prados 1994a: 467.-Altuna Prados 1994b: 55 (annex, listed).Altuna Prados 1994c: 71, fig. 1.-Álvarez Claudio 1994: 465.-Altuna 1995: 92 (tab. 1, listed).-Cairns and Chapman 2001: 36 (tab. 1, listed).-Brito and Ocaña 2004: 387, pl. 84, figs. A-G.-Reveillaud et al. 2008: 322 (tab. 1, listed), fig. 4.-Altuna 2010: 21 (listed).Louzao et al. 2010: tab. S1 (listed).-Altuna 2012: 402 (tab. 2, listed).-Altuna 2013: 105 (tab. 2, listed).

Material examined V-2010: Stn. DR04-A0710, 128 m, 1 small broken specimen on a mollusk shell.

Description Corallum solitary, small $(\mathrm{H}=8.0 \mathrm{~mm})$, fixed, subcylindric, slightly widening distally, not pedicellated. Wall only distally costate, with low rounded costae $\mathrm{C} 1-\mathrm{C} 2>\mathrm{C} 3>\mathrm{C} 4$, and shallow intercostal furrows. Wall with numerous minute pointed granules. Calice almost round in calicular view with $\mathrm{GCD}=8.0 \mathrm{~mm}$ and $\mathrm{LCD}=7.0 \mathrm{~mm}$. Septa hexamerally arranged in 4 cycles and 6 systems (48 septa) according to the formula S1$\mathrm{S} 2>\mathrm{S} 3>\mathrm{S} 4$. Septa thick and poorly exsert. S1 independent, connected to the columella through a palus. S3 join S2 near columella by the fusion of the inner edges of their pali, and S4 join S3 at the middle of the fossa, reaching the columella as a single septum. Cycles 1-2 paliferous (P1-P3), with pali granulated and separated by a narrow notch from septa. Septal faces with apparent, rounded granules and small carinae. Fossa shallow, containing a well-developed columella formed by small rods, with P1 and P2 merging into it. Due to the relative sizes of septa, pali, and columella, the fossa appears rather 'full' of calicular elements.

Remarks In being a species capable of reaching 20-30 mm in height, although hardly reaching 96 septa (Zibrowius 1980), the specimen at study is considered a young. It lacks S5, and according to Cairns (1979), these septa begin to appear above a calicular diameter of about $8.0 \mathrm{~mm}$.

Paracyathus pulchellus is rarely recorded in the Bay of Biscay and nearby areas. It only occurs on its southern sector, with its northern distributional boundary located in the Landes Province (France, southeast of the bay) with a record from Fischer (1872). The species has been absent from the literature of the Bay of Biscay for many years since the papers of Fischer (1872), de Folin and Périer (1875), de Folin (1887) and Marion (1906) [all as Paracyathus striatus (Philippi 1842)], and its presence therein needed confirmation according to Zibrowius (1980). Subsequently to Zibrowius (1980), the species has been seldom collected and never in abundance from the southern sector of the Bay of Biscay by Aguirrezabalaga et al. (1988), Álvarez Claudio (1993) and Altuna Prados (1994a).

If compared to other areas like the Mediterranean Sea or the south of Portugal (see Zibrowius and Saldanha 1976, as Monomyces anthophyllum Ehrenberg 1834; Zibrowius 1980, $6 \mathrm{~m}$ depth) where this coral has been collected at shallow depths, the bathymetric range of the species is narrower in the Bay of Biscay. Paracyathus pulchellus is distributed in this area from the deep circalittoral to the upper bathyal, in a depth range of 73-425 m after a review of the literature (latter depth doubtful, see Marion 1906: 116). Depth of Stn. DR04-A0710 (128 m) is in accordance with the range of 40-1,260 m given by Cairns and Chapman (2001) for the species in the eastern Atlantic.

This coral is amphi-Atlantic in tropical and subtropical areas with a limited expansion to high latitudes of both hemispheres. It is widely distributed from the southeast of the Bay of Biscay to the Guinea Gulf, including in the Mediterranean Sea, the Canary Islands, Azores, and Madeira (see Zibrowius 1980), and in the western Atlantic from the east coast of the USA to Brazil with several records from the Caribbean Sea (Cairns 1979; Reyes et al. 2009). There is a significant distributional gap in the Atlantic coast of the Iberian Peninsula from the south of Portugal (record of Zibrowius and Saldanha 1976) to off 
Asturias (record of Álvarez Claudio 1993, and the present paper).

Premocyathus cornuformis (de Pourtalès 1868) (Fig. 5h, i)

Caryophyllia cornuformis de Pourtalès 1868: 133.Zibrowius 1980: 66, pl. 26, figs. A-L.-Monteiro Marques and Andrade 1981: 88 (listed).-Zibrowius 1985: 314 (tab. 2, listed), 316.-Álvarez Claudio 1993: 417 (listed)._Álvarez Claudio 1994: 464._-Molodtsova et al. 2008: 118, fig. 2B.-Altuna 2010: 21 (listed).Louzao et al. 2010: tab. S1 (listed).

Premocyathus cornuformis: Cairns and Chapman, 2001: 37 (tab. 1, listed).- Reveillaud et al. 2008: 322 (tab. 1, listed), fig. 4.-Altuna 2012: 402 (tab. 2, listed), fig. 1.7.-Altuna 2013: 105 (tab. 2, listed).

Material examined P-2011: Stn. V02-A0511, 1,008 m, 1 dead specimen, eroded.

Description Corallum unattached, $14.2 \mathrm{~mm}$ in height and $24.6 \mathrm{~mm}$ long considering its curvature, trochoid, strongly curved, narrowing to base. Base $3.0 \mathrm{~mm}$ wide, broken. Wall almost fully costate except near base, with neat horizontal growth marks and numerous small granules. Costae equal in width, flat, smooth except near the calicular edge, where they are rugose. Intercostals furrows shallow, notably deeper near calicular margin. Calice round, with $\mathrm{GCD}=\mathrm{LCD}=8.0 \mathrm{~mm}$. Twenty-five septa arranged in 3 cycles according to the formula $\mathrm{S} 1>\mathrm{S} 2 \geq \mathrm{S} 3$, with $\mathrm{S} 1$ extending farther toward the columella than $\mathrm{S} 2$, and these than S3. S1 slightly exsert, with further cycles progressively less exsert. Septal faces almost smooth. Inner edges of septa straight, smooth, descending vertically into a deep fossa. Palar crown absent, with only one P2 as a lamellar plate with a few granules. Columella formed by two twisted lamellae.

Remarks Depth is in accordance with previous data from the Bay of Biscay and nearby areas after a review of the literature (700-2,360 m).

According to Zibrowius (1980), P. cornuformis is known in the eastern Atlantic from the north of the Bay of Biscay to Morocco, including the island of Madeira and the Azores archipelago. Its northernmost record is in the north of the Bay of Biscay at $47^{\circ} 39^{\prime} \mathrm{N}-08^{\circ} 11.8^{\prime} \mathrm{W}$ (see Zibrowius 1985), but there are old further north records in the western Atlantic by Lindström (1877, as Caryophyllia pourtalesi Duncan 1873) and Jourdan (1895), as Caryophyllia communis (Seguenza 1863). In the Western Atlantic there are significant distributional gaps, with records from Newfoundland, Florida, Caribbean Sea, Antilles and off the Brazilian coast (Cairns 1979). It was recently collected from the Mid-Atlantic Ridge by Molodtsova et al. (2008).

Citations from the Bay of Biscay are not abundant, although there are records from the northern and southern sectors including the Avilés Canyon System (Zibrowius 1980, 1985; Monteiro Marques and Andrade 1981; Álvarez Claudio 1994).

Solenosmilia variabilis Duncan 1873 (Fig. 5j) Solenosmilia variabilis Duncan 1873: 328, pl. 42, figs. 11-18.-Zibrowius 1980: 143, pl. 75, figs. AN.-Monteiro Marques and Andrade 1981: 88 (listed).-Zibrowius 1985: 314 (listed, tab. 2), 318.Ramil Blanco and Fernández Pulpeiro 1990: 27.—? Paulmier 1997: 13, pl. 11, fig. 4, pl. 12, fig. 1.-Cairns and Chapman 2001: 37 (tab. 1, listed).-SchröderRitzrau et al. 2005: 160 (tab. 1, listed).-Reveillaud et al. 2008: 322 (tab. 1, listed), fig. 4.-Altuna 2010: 21 (listed).-Altuna 2012: 402 (tab. 2, listed).-Altuna 2013: 105 (tab. 2, listed).

Material examined P-2010: Stn. DR15-A0410, 1,660 m, several colonies.-Stn. DR17-A0410, 1,476 m, several big-sized colonies.-Stn. DR18-A0410, $767 \mathrm{~m}$, some fragments.-Stn. DR22-A0410, 2,291 m, several colonies.-Stn. DR23-A0410, 1,706 m, 2 small fragments.Stn. DR24-A0410, 1,533 m, several fragments. P-2011: Stn. G03-A0511, 1,464 m, several fragments. O-2012: Stn. ROV8-A0912, 1,576 m, a small fragment.

Remarks Solenosmilia variabilis was known previously in the Bay of Biscay and nearby areas in a depth range of 676-2,034 m depth, and it has been collected during the surveys in the Avilés Canyon System between 767 and 2,291 m depth. Cairns (2010) gives a depth range of 220-2,165 $\mathrm{m}$ for the species worldwide.

This coral was not recorded in previous surveys in the canyon by Álvarez Claudio (1994). It can be locally abundant at deeper depths than the other constructors that thrive in the canyon (L. pertusa and M. oculata), and bigsized colonies were collected in some stations. This coral is probably more abundant in the Bay of Biscay than is shown by the limited records that are available from the literature, and very likely it has been confused with other species.

Solenosmilia variabilis has been recorded worldwide. In the eastern Atlantic, it is known from Greenland and Ireland, Bay of Biscay, Atlantic coast of the Iberian Peninsula, Morocco, Western Sahara, Azores, Madeira, Guinea Gulf (Zibrowius 1980), Canary Islands (Brito and Ocaña 2004), and further south to South Africa (Cairns and Parker 1992). 
Stephanocyathus moseleyanus (Sclater 1886) (Fig. 6a-f) Stephanocyathus moseleyanus: Altuna 2012: 402 (tab. 2, listed), fig. 1.10.-Altuna 2013: 115, figs. 4G-H, tabs. 1-3 (listed).

Material examined P-2011: Stn. G03-A0511, 1,464 m, 1 specimen.-Stn. G06-A0511, 1,244 m, 3 specimens.-Stn. V03-A0511, 1,473 m, 4 specimens, 3 dead, and a small young.

Remarks The material is formed by 8 specimens ranging from $9.0 \mathrm{~mm}$ to $50.5 \mathrm{~mm}$ in GCD (both from Stn. V03A0511). Some of the specimens are close to the largest specimens known so far from the northeast Atlantic (see Zibrowius 1980, 55-60 $\mathrm{mm}$ in GCD). Smallest specimen is star-shaped in calicular view and has 41 septa in four cycles, with the last incomplete. The base is broken, and the six protosepta are clearly seen. Larger specimens are almost round in calicular view, discoidal, with a nearly flat (see Gravier 1920, pl. 5, fig. 76) to slightly concave base and have up to 88 septa in five cycles. A full fifth cycle is not attained. The specimens have 12 dominant septa S1-S2 that are equal in size and highly exsert. $\mathrm{S} 1$ are independent septa, whether S2 are joined directly by S3 near columella, and $\mathrm{S} 3$ by $\mathrm{S} 4$. S5 also remain independent, and follow S1$\mathrm{S} 2$ in their exsert projection. S3-S4 are only slightly exsert. In some specimens the columella is much developed, merging the junction between S2 and S3 that cannot be distinguished.

Fresh specimens are deep purple in color, and their flesh is particularly thick and hard, perhaps due to a welldeveloped mesoglea. The color is persistent in specimens stored in ethanol.

Stephanocyathus moseleyanus occurs mainly in a depth range of 1,000-2,000 $\mathrm{m}$ depth and rarely out of these limits (Zibrowius 1980). Depth range in the Bay of Biscay is 867-1,900 m. Hence, records from the Avilés Canyon $(1,266-1,473 \mathrm{~m})$ are consistent with the depth range expected for the species in the study area.

This is a coral widely distributed in the eastern Atlantic from Iceland to Guinea, including the Canary Islands and the archipelagos of Azores and Madeira (Zibrowius 1980). It is also known from the northern and southern sectors of the Bay of Biscay (Roule 1896; Zibrowius 1980; Altuna 1995, 2013), including the Avilés Canyon System (Álvarez Claudio 1994).

Stephanocyathus nobilis (Moseley 1873) (Fig. 6g-k)

Stephanocyathus nobilis: Zibrowius 1980: 101, pl. 51, figs. A-K.-Monteiro Marques and Andrade 1981: 88 (listed).-Zibrowius 1985: 314 (tab. 2, listed), 317. Ramil Blanco and Fernández Pulpeiro 1990: 27.Cairns and Chapman 2001: 37 (tab. 1, listed).-
Reveillaud et al. 2008: 322 (tab. 1, listed), fig. 4.Altuna 2010: 21 (listed).-Altuna 2012: 402 (tab. 2, listed).

Material examined P-2010: Stn. DR24-A0410, 1,533 m, 4 dead corallites. P-2011: Stn. V03-A0511, 1,473 m, 1 specimen.

Remarks The material consists in five specimens $18.6-23.5 \mathrm{~mm}$ in height for $\mathrm{GCD}=31.0-43.0 \mathrm{~mm}$. Coralla are stout and have an almost horizontal base with 12 characteristic elongated tubercles on its edge, arising from each of $\mathrm{C} 1-\mathrm{C} 2$. Calices are almost round to very slightly elliptical in the larger specimens, having up to 84 septa arranged in 4 complete cycles S1-S4. A full fifth cycle is not attained. All specimens have 12 dominant septa $\mathrm{S} 1-\mathrm{S} 2$ that are equal in size and highly exsert. S1-S3 merge with columella, and S4 join normally S3 near columella, although may also remain independent. S5 are independent and follow $\mathrm{S} 1-\mathrm{S} 2$ in their exsert projection; S3-S4 are only faintly exsert.

This is a well-known species in the Bay of Biscay, to be found usually in the middle and lower parts of the continental slope (Zibrowius 1985). It is more frequently recorded in the Bay of Biscay than $S$. moseleyanus, with most part of the records given from the southern sector of the bay, further south than the $44^{\circ} \mathrm{N}$ parallel (off Spain) (see Gravier 1920; Zibrowius 1980, 1985; Monteiro Marques and Andrade 1981).

Station V03-A0511 $(1,473 \mathrm{~m})$ is the shallowest for the species in the Bay of Biscay and nearby areas, which was previously known in a depth range of 1,490-2,170 $\mathrm{m}$ after a review of the literature. Like $S$. moseleyanus, fresh specimens are deep purple in color, which is persistent in specimens stored in ethanol.

Stephanocyathus nobilis is known in a depth range of 1,300-2,200 m from the Rockall Trough to Sierra Leona, with records from the Bay of Biscay, Portugal and the Ibero-Moroccan Gulf, Madeira and Azores archipelagos, and the Mid-Atlantic Ridge (Zibrowius 1980). In the Bay of Biscay, it is known from the northern and southern sectors, although records are more abundant approximately south of the $44^{\circ} \mathrm{N}$ parallel with records from Gravier (1920), Zibrowius (1980, 1985), and Monteiro Marques and Andrade (1981).

Vaughanella concinna Gravier 1915 (Fig. 61-o)

Vaughanella concinna Gravier 1915: 2, 10.-Zibrowius

1980: 104, pl. 52, figs. A-K, pl. 53, figs. A-L.Zibrowius 1985: 314 (tab. 2, listed), 317.-Álvarez Claudio 1994: 465.- Cairns and Chapman 2001: 37 (tab. 1, listed).-Brito and Ocaña 2004: 3379.-Reveillaud et al. 2008: 322 (tab. 1, listed), fig. 4.-Altuna 
a

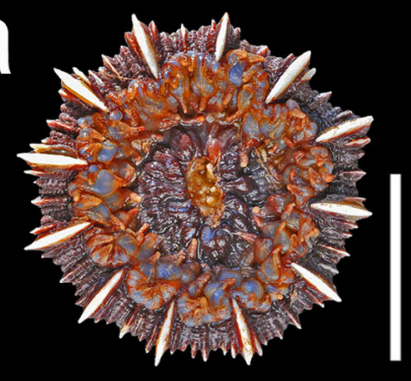

d

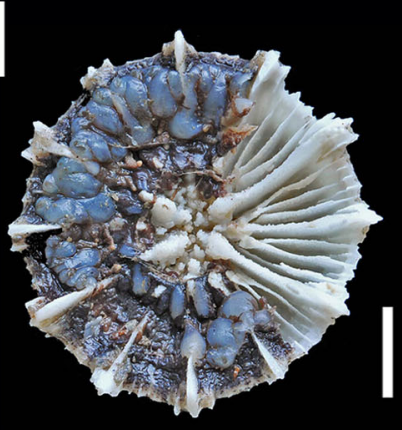

g

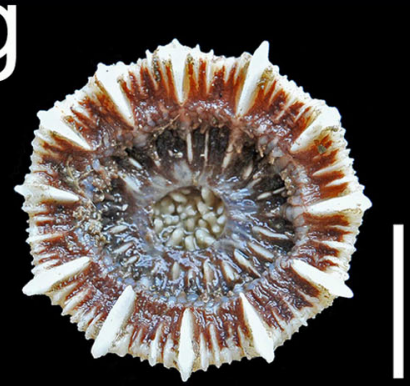

j

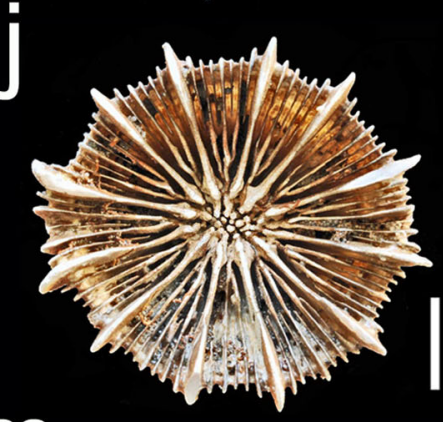

$\mathrm{m}$

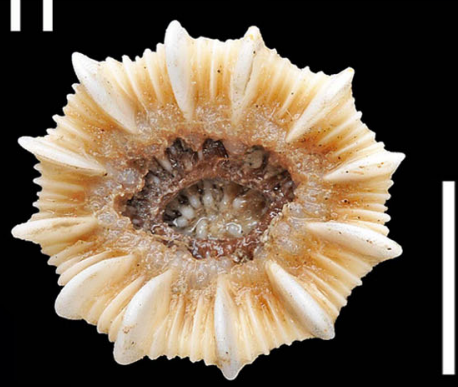

b

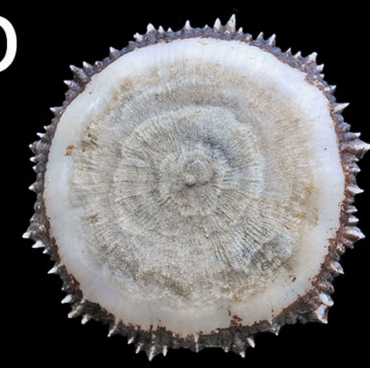

Q

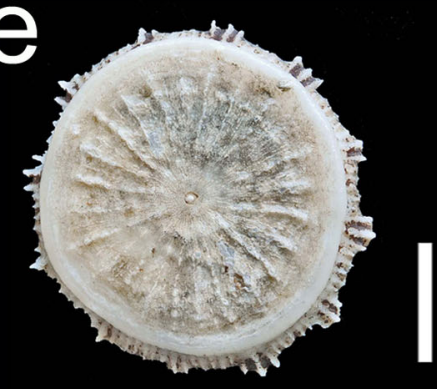

h
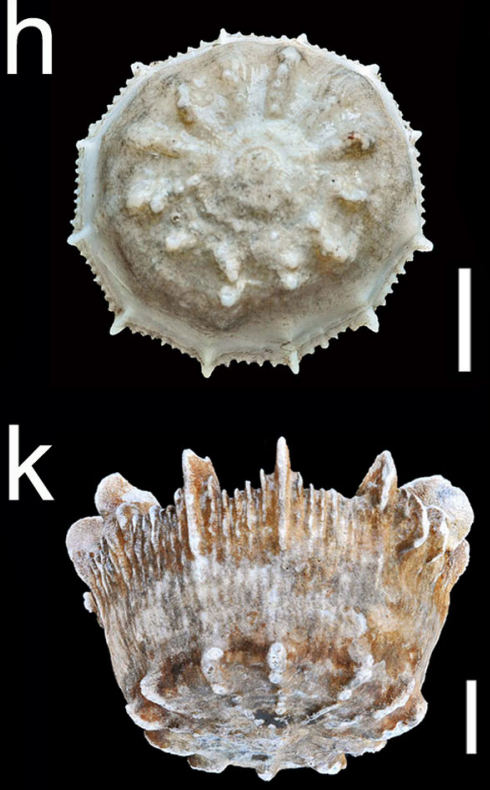

n

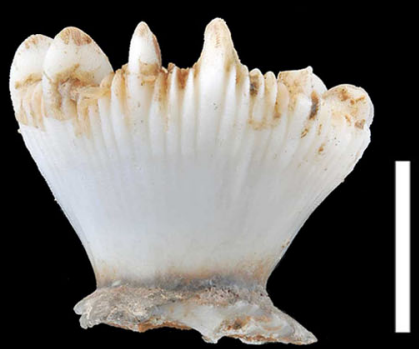

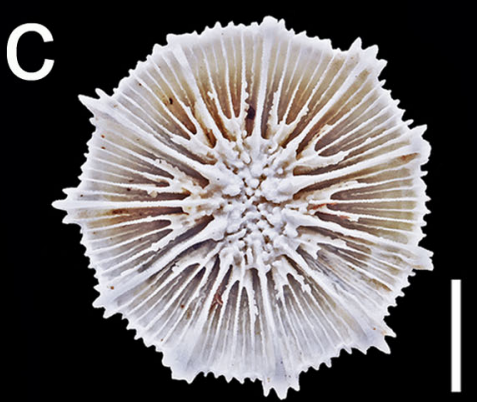

5

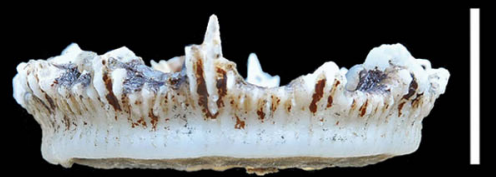

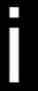



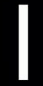

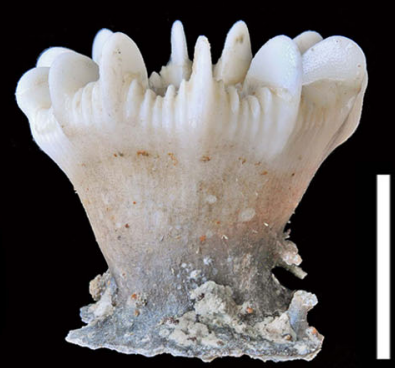

0




४Fig. 6 Stephanocyathus moseleyanus (Sclater 1886). a A specimen in calicular view, Stn. G06-A0511 (P-2011). b Same specimen seen from below. c Calice, Stn. V03-A0511 (P-2011). d Calice, Stn. V03A0511 (P-2011). e Same specimen seen from below. f Same specimen in side view. Stephanocyathus nobilis (Moseley 1873). g Calice, Stn. V03-A0511 (P-2011). h Same specimen seen from below. i Same specimen in side view. j Calice, Stn. DR24-A0410 (P-2010). k Same specimen in side view. Vaughanella concinna Gravier 1915. I Corallum in side view, Stn. DR05-A0511 (P-2011). m Same specimen in calicular view. n Corallum in side view, Stn. DR15-A0410 (P-2010). o Same specimen seen from below. Scale bar $\mathbf{a}, \mathbf{b}=25 \mathrm{~mm} ; \mathbf{c}, \mathbf{e}, \mathbf{f}$, $\mathbf{g}, \mathbf{l}-\mathbf{o}=15 \mathrm{~mm} ; \mathbf{d}, \mathbf{h}-\mathbf{k}=10 \mathrm{~mm}$

2010: 21 (listed)._Altuna 2012: 402 (tab. 2, listed), fig. 1.11.-Altuna 2013: 105 (tab. 2, listed).

Material examined P-2010: Stn. DR15-A0410, 1,660 m, 1 specimen. P-2011: Stn. DR05-A0511, $908 \mathrm{~m}, 1$ specimen.

Description Corallum solitary, cup-shaped, tapering quickly to proximal end, stout, with $\mathrm{H}=20.0-27.0 \mathrm{~mm}$, attached by a wide pedicel of about one-half the calicular diameter, expanding in a wide base over the substrate. Wall glossy, finely granular, with only its distalmost half costate. $\mathrm{C} 1-\mathrm{C} 2$ subequal and wider than $\mathrm{C} 3-\mathrm{C} 5$, all flat to slightly ridged distally with apparent intercostals furrows near calicular margin, finely and uniformly granulated. Calice slightly elliptical, $29.0-30.0 \mathrm{~mm}$ in GCD and 27.0-28.0 $\mathrm{mm}$ in LCD (GCD: LCD = 1.07), with 68 septa hexamerously arranged in 4 complete cycles $\mathrm{S} 1-\mathrm{S} 4$, and an incomplete S5 (20 septa). S1-S2 subequal, dominant, and highly exsert (5.0 $\mathrm{mm}$ from calicular margin); S3-S5 considerably less exsert. Three-five S3-S5 occur between two dominants. S4 normally join in front of S3 deep in the fossa, near columella; S5 poorly developed. Upper margins of septa even, turning finely granulated in the axial margin, deep in the fossa. Lateral faces uniformly adorned with minute septal granulation. S1-S4 with more or less apparent P1-P4 close to columella. Fossa wide, deep. Columella small, slightly elongated, formed by a few rods isolated or fused, finely granulated, and some of the paliform lobes of septa.

Remarks Station DR05-A0511 (908 m) is shallower than the range of 1,022-3,018 $\mathrm{m}$ given by Cairns and Chapman (2001) for the species in the eastern Atlantic. Records from the Bay of Biscay and nearby areas are from a depth range of 540-2,170 m (Zibrowius 1980, 1985; Álvarez Claudio 1994), with the former depth considered doubtful by $\mathrm{Zi}$ browius (1980).

The specimens at study do not have a complete cycle S5. They normally have five septa on each of the 12 compartments between two dominants, and rarely three. According to Gravier (1920: 64), if there are three, they correspond to $1 \mathrm{~S} 3$ and $2 \mathrm{~S} 4$. If there are five, these are $1 \mathrm{~S} 3$, $2 \mathrm{~S} 4$, and $2 \mathrm{~S} 5$. One of the S4, at both sides of which one S5 is formed, acquires a similar development than the S3 and joins to it deep in the fossa.

This coral is distributed from the northern sector of the Bay of Biscay to the Azores and Madeira archipelagos (Zibrowius 1980). It is uncommon in the Bay of Biscay and has been recorded only from a few stations from the northern and southern sectors (Zibrowius 1980, 1985), including the Avilés Canyon System (Álvarez Claudio 1994).

Family Flabellidae Bourne, 1905

Flabellum alabastrum Moseley 1873 (Fig. 7a-d)

Flabellum alabastrum: Zibrowius 1980: 148, pl. 77, figs. A-J.-Monteiro Marques and Andrade 1981: 88 (listed).-Zibrowius 1985: 314 (tab. 2, listed), 318.Zibrowius and Gili 1990: 38, pl. 2S-T.-Álvarez Claudio 1993: 418 (listed)._Álvarez Claudio 1994: 466.Cairns and Chapman 2001: 36 (tab. 1, listed).-Molodtsova et al. 2008: 119, fig. 2E.-Reveillaud et al. 2008: 322 (tab. 1, listed), fig. 4.-Altuna 2010: 21 (listed).Louzao et al. 2010: tab. S1 (listed)._Altuna 2012: 402 (tab. 2, listed), fig. 1.14.-Altuna 2013: 105 (tab. 2, listed).

Material examined P-2010: Stn. DR15-A0410, 1,660 m, 1 specimen. P-2011: Stn. V03-A0511, 1,473 m, 1 dead and broken specimen.

Description Corallum flabelliform (Stn. DR15-A0410), with $\mathrm{H}=50.0 \mathrm{~mm}$, laterally compressed (slightly more at the center of the wall), forming an arch of $102^{\circ}$, pedicellated. Calice curved in lateral view and elongated in calicular view, with $\mathrm{GCD}=62.0 \mathrm{~mm}$ in projection, $\mathrm{LCD}=19.0-22.0 \mathrm{~mm}$ and GCD: $\mathrm{LCD}=2.8-3.2$. Calicular margin strongly and regularly cusped due to the equally exsert projection of septa S1-S3. Wall costate, with C1-C3 well-developed and C4-C5 inconspicuous. Ninety-six septa in 5 complete cycles S1-S5, arranged according to the formula $\mathrm{S} 1-2>\mathrm{S} 3 \gg \mathrm{S} 4>\mathrm{S} 5$. S1-2 extending slightly farther toward the columella than the other septa. S1-S3 strongly and equally exsert, S4 less exsert, with S5 following S1-S3 in their projection. Inner edges of S1-S3 descend vertically deep into the fossa. Lateral faces of septa smooth or with a few scattered granules. Growth lines very apparent. Fossa very deep, with an elongated narrow columella in its center, smooth, formed by the convergence of S1-S3. Tentacles fully contracted, apparently short, with stalks covered by numerous vesicles rich in spirocysts. Soft tissues deep red to maroon in ethanol; tip of tentacles lighter.

Remarks The specimen from Stn. V03-A0511 is dead and much eroded. It has 54 septa for $\mathrm{GCD}=29.0 \mathrm{~mm}$ (roughly, broken specimen), the costae are well marked, 




Fig. 7 Flabellum alabastrum Moseley 1873. a Corallum in side view, Stn. DR15-A0410 (P-2010). b The same specimen in calicular view. c Calice, Stn. V03 (P-2011). d Same specimen seen from below. Flabellum chunii Von Marenzeller 1904, Stn. V03-A0511 (P2011). e Corallum in side view. Note characteristic erosion of the wall by Lumbrineris. Flabellum macandrewi Gray 1849, Stn. DR 12-A0410 (P-2010). f Corallum in side view. Monomyces pygmaea
(Risso 1826), Stn. DR08-A0511 (P-2011). g Corallum in side view. Note root-like basal projections. h Same specimen in calicular view. Javania cailleti (Duchassaing and Michelotti 1864). i Corallum in side view, Stn. DR15-A0410 (P-2010). j Corallum, Stn. DR16-A0410 (P-2010). k Calice of the same specimen. Scale bar $\mathbf{a}, \mathbf{b}=20 \mathrm{~mm}$; c$\mathbf{f}, \mathbf{j}, \mathbf{k}=10 \mathrm{~mm} ; \mathbf{g}=5 \mathrm{~mm} ; \mathbf{h}=4 \mathrm{~mm} ; \mathbf{i}=15 \mathrm{~mm}$ 
and the wall has numerous growth marks. It certainly looks like a specimen of Flabellum macandrewi Gray 1849 illustrated by Zibrowius (1980, pl. 107, fig. I), but in this species, there is no columella or it is rudimentary, whether the corallite from Avilés has a well-developed longitudinal spongy structure with dominant septa merging with it. Equal-sized corallites of Flabellum chunii Von Marenzeller 1904 have much more septa.

The specimen from Stn. DR15-A0410 has a strongly cusped calicular margin (genus Ulocyathus M. Sars, 1851, see Cairns 1989). The corallum is stout if compared with more usual $F$. alabastrum specimens examined by the authors from the Galicia Bank (INDEMARES 2011, unpublished), which are fragile and light and have thin wall and septa.

Records from the canyon are consistent with the depth range known for the species in the Bay of Biscay and nearby areas after a review of the literature (800-2,177 m).

Flabellum alabastrum is known at both sides of the Atlantic, but extending further south in the eastern Atlantic. Records in this area are numerous, and the species is known from the west of Scotland and southwest of Ireland, to the Guinea Gulf, including the Bay of Biscay, the Atlantic coasts of the Iberian Peninsula, Morocco, Azores and Madeira archipelagos, and Cape Verde Islands ( $\mathrm{Zi}-$ browius 1980). It was recently collected from the MidAtlantic Ridge (Molodtsova et al. 2008). Its southern range was extended considerably by Zibrowius and Gili (1990) record from Namibia. In the Bay of Biscay, it has been collected from the northern (Roule 1896; Zibrowius 1980) and southern sectors (Zibrowius 1980; Monteiro Marques and Andrade 1981), including the Avilés Canyon System (Álvarez Claudio 1994).

Flabellum chunii Von Marenzeller 1904 (Fig. 7e)

Flabellum chunii Von Marenzeller 1904: 274, pl. 18, figs. 14, 14a-14b.-Altuna 2012: 402 (tab. 2, listed), fig. 1.13.-Altuna 2013: 116, figs. 5A-D, tabs. 1-3 (listed).

Material examined P-2011: Stn. V03-A0511, 1,473 m, 1 dead and broken specimen.

Description Corallum solitary and unattached, flabellate, $\mathrm{V}$-shaped in edge view, $\mathrm{H}=21.6 \mathrm{~mm}$, laterally compressed, with a small pedicel. Wall light purple and whitish, much corroded by commensal polychaete. Costae poorly developed, subequal, obscured by a few distal apparent transverse growth marks. Two basal processes present. Calice forming an arch of $106^{\circ}, 42.0 \mathrm{~mm}$ long, with an elliptical projection in the plane of $\mathrm{GCD}=28.0 \mathrm{~mm}$ and $\mathrm{LCD}=14.0 \mathrm{~mm}$. Septa 103 , not exsert, arranged in five complete cycles S1-S5, and a few additional S6. Septa thin, descending vertically into fossa, with upper margins smooth and septal faces with scarce small pointed granules. S1-S3 dominant, subequal in width, and S4-S6 thinner. S1-S3 merge with columella deep in the fossa, with inner edges thickened near columella. Columella deep, narrow, trabecular.

Remarks The specimen was dead, and its wall is corroded by Lumbrineris as usually in this species in other geographic areas (Zibrowius 1980). This corrosion has been observed previously between 160 and $623 \mathrm{~m}$ depth in the northeast Atlantic (Zibrowius 1980) including the Galicia Bank (Altuna 2013, $924 \mathrm{~m}$ ). Although the specimen is dead and bad preserved, there is no doubt about its identity when comparing the specimen with similar-sized coralla from the Galicia Bank (see Altuna 2013). Three were the species of Flabellum Lesson, 1831 known up til now from the Bay of Biscay and nearby areas, namely $F$. angulare Moseley $1876, F$. alabastrum, and F. macandrewi. Flabellum chunii is distinctive by its habitus, the higher number of septa and the characteristic corrosion by Lumbrineris. The specimen at study is relatively small $(\mathrm{GCD}=28.0 \mathrm{~mm})$, but it has already 103 septa. Comparatively, adult specimens of $F$. alabastrum have 96 septa for $\mathrm{GCD}=80 \mathrm{~mm}$, and of $F$. angulare, 96 for GCD $=70 \mathrm{~mm}$ (see Zibrowius 1980).

The depth of Stn. V03-A0511 (1,473 m) is exceptional for the species, which lives in a depth range of 200-700 m depth (Zibrowius 1980; Cairns 2010), but the specimen was collected dead and this depth must be considered with caution.

Flabellum chunii is a coral of a northeastern Atlantic distribution, known from Portugal, Ibero-Moroccan Gulf, Morocco, Western Sahara, and Madeira and Azores archipelagos (Zibrowius 1980). It was recently mentioned from the Galicia Bank (Altuna 2013). This is the first record of the species from the Bay of Biscay and the northernmost citation. According to new data given herein, its geographic range is extended significantly.

Flabellum macandrewi Gray 1849 (Fig. 7f)

Flabellum macandrewi: Zibrowius 1980: 150, pl. 78, figs. A-L, pl. 107, figs. H-I.-Altuna 2013: 117, figs. $5 \mathrm{E}-\mathrm{G}$.

Material examined P-2010: Stn. DR12-A0410, 828 m, 1 broken specimen.

Remarks The species was collected recently by Altuna (2013) also from the Bay of Biscay. The specimen at study is $23.0 \mathrm{~mm}$ in height for a $\mathrm{LCD}=17.0 \mathrm{~mm}$. In being a broken specimen, GCD could not be ascertained. The wall is glossy, with well-developed costae. In the calicular margin, highly exsert S1-S2 are distinctive. 
Depth of collection is in accordance with previous data from the Bay of Biscay and nearby areas (746-930 m, see Zibrowius 1980; Lavaleye et al. 2002; Altuna 2013).

This is a coral widely distributed in the eastern Atlantic. It is uncommon in the whole Bay of Biscay and nearby areas, although it may be abundant at certain areas of its southern sector like Le Danois Bank off Spain (Zibrowius 1980; Altuna 2013).

\section{Flabellum sp.}

Material examined P-2010: Stn. DR11-A0410, 636 m, 1 specimen.

Remarks The specimen is a broken flabellate corallite $\mathrm{V}$-shaped in edge view, with its distal half missing, $20.0 \mathrm{~mm}$ in width, much eroded and subfossil. Not identifiable.

Javania cailleti (Duchassaing and Michelotti 1864) (Fig. 7i-k)

Javania cailleti: Zibrowius 1980: 157, pl. 82, figs. A-L.-Zibrowius 1985: 314 (tab. 2, listed), 319.-_Ramil Blanco and Fernández Pulpeiro 1990: 28.-Cairns and Chapman 2001: 36 (tab. 1, listed).-Reveillaud et al. 2008: 322 (tab. 1, listed), fig. 4.-Altuna 2010: 21 (listed).-Altuna 2012: 402 (tab. 2, listed).

Material examined P-2010: Stn. DR15-A0410, 1,660 m, 2 specimens, one dead.-Stn. DR16-A0410, 1,818 m, 1 dead specimen.-Stn. DR17-A0410, 1,476 m, 1 specimen on coral debris.-Stn. DR22-A0410, 2,291 m, 2 specimens and some fragments, all dead.

Description Corallum solitary, ceratoid, attached, $\mathrm{H}=$ $38.0-47.3 \mathrm{~mm}$, formed by a wide and thin basal plate, expanding through a thin pedicel 5.0-7.7 $\mathrm{mm}$ in diameter into a large, round to elliptical calice. Theca snow white, porcelanous, glossy, smooth, only distally costate near calicular margin, with $\mathrm{C} 1-\mathrm{C} 2$ faint developed, subequal. Calices round to elliptical, flared, ranging between 25.7 and $37.0 \mathrm{~mm}$ in GCD, and 23.0-28.4 $\mathrm{mm}$ in LCD, with GCD: $\mathrm{LCD}=1.03-1.30$. Septa 48 arranged in 4 cycles and 6 systems, according to the formula $\mathrm{S} 1-\mathrm{S} 2>\mathrm{S} 3>\mathrm{S} 4$. S1-S2 equally and highly exsert, S3 less exsert, and S4 only slightly exsert or not at all. Septa descending vertically into the fossa, with inner edges normally straight or sinuous deep in the fossa, particularly S3-S4. S1-S2 extending equally to columella and merging with it, more than S3, and these much more than S4. Lateral faces granulated, with small granules, mostly pointed. Fossa deep, straight, with a poorly developed and compact columella.

Remarks The material is distinctive in having a snow white and glossy wall, a well-defined long and straight pedicel, a deep fossa, and a notably flared calice. The corallum typically tapers from calicular margin to base, and S1-S2 are highly exsert.

Depth of station DR22-A0410 (2,291 m, only dead specimens) is deeper than previous records from the Bay of Biscay and nearby areas $(915-2,150 \mathrm{~m}$, see Zibrowius $1980,1985)$ and to the depth given for the species by Cairns (2010) worldwide (30-2,165 m). In being glossy and well-preserved specimens despite their delicacy, we consider that they hardly were rolled from shallower bathymetric levels and the species probably lives at this depth in the canyon system.

Javania cailleti has a wide distribution that, according to Zibrowius (1980), includes the western Atlantic (from Nova Scotia to Uruguay) and the Pacific and Indian Oceans. This author studied material collected in the northeastern Atlantic from the Celtic Sea, Bay of Biscay, Mediterranean Sea, Morocco, Madeira, and Azores. However, records from the Bay of Biscay are scarce, and the species is known only from a few stations from the northern and southern sectors (see Zibrowius 1974, 1980, 1985).

Monomyces pygmaea (Risso 1826) (Fig. 7g, h)

Monomyces pygmaea: Zibrowius 1980: 154, pl. 80, figs. A-L.-Altuna Prados 1993: 52.-Altuna Prados 1994a: 480, pl. 10, fig. D.-Altuna Prados 1994b: 55 (annex, listed).-Altuna Prados 1994c: 75, fig. 1.-Altuna 2010: 21 (listed).-Altuna et al. 2010: 3.-Altuna 2012: 402 (tab. 2, listed), fig. 1.15.

Material examined P-2011: Stn. DR08-A0511, 55 m, 1 corallite.

Description Corallum a laterally compressed cylinder $12.0 \mathrm{~mm}$ in height, solitary, slightly curved to one side, attached to substrate by a narrow and elongated base. Base reinforced with rootlets; basal plate much reduced. Wall thin, light brown, not costate, with numerous horizontal wrinkles. Calice elliptical, $\mathrm{GCD}=11.0 \mathrm{~mm}$, $\mathrm{LCD}=9.0 \mathrm{~mm}$, with margin smooth. Septa 39, nonexsert, arranged hexamerally in three complete cycles S1$\mathrm{S} 3$ with a few additional S4, according to the formula S1$\mathrm{S} 2>\mathrm{S} 3>\mathrm{S} 4$. S1-S2 dominants, S1-S3 descending vertically into fossa, and S4 much reduced, commonly formed by a few spines on the middle of the wall. Septal faces with apparent, scattered, pointed granules. Inner edges of S1-S3 wavy near columella, with S1-S2 merging with it. Fossa deep, with an elongated, straight and spongy columella.

Remarks This is the shallowest record from the Bay of Biscay, with previous records from 60 to $80 \mathrm{~m}$ depth (Altuna Prados 1994a, c). 
Monomyces pygmaea is a stenobathic coral known from the Bay of Biscay to Cape Verde Islands including the Mediterranean Sea (Zibrowius 1980; Altuna Prados 1994a, c). It rarefies northward along the Atlantic coasts of the Iberian Peninsula and is an uncommon southern species in the Bay of Biscay. From Setubal (see Zibrowius and Saldanha 1976) to the Bay of Biscay, it has been collected only a few times from Galicia (Altuna et al. 2010), and the Basque coast (Altuna Prados 1994a, c, northernmost record). Heretofore, there are no records in hard substrates at shallow depths in the Bay of Biscay as it occurs in the Mediterranean Sea and the south of Portugal (see $\mathrm{Zi}$ browius 1980), although there is a single record at shallow depths from Galicia (northwest Spain, Altuna et al. 2010).

Suborder Dendrophylliina Vaughan and Wells, 1943

Family Dendrophylliidae Gray, 1847

Balanophyllia thalassae Zibrowius 1980 (Fig. 8c-h)

Balanophyllia thalassae Zibrowius 1980: 189, pl. 96, figs. A-I.-Altuna 2012: 402 (tab. 2, listed), fig. 1.17.Altuna 2013: 120, figs. 6A-D, tabs. 1-3 (listed).

Material examined P-2010: Stn. DR04-A0410, 700 m, 4 specimens, 1 dead, two growing on the dead specimen.Stn. DR18-A0410, 767 m, 13 specimens, some growing on corals debris. P-2011: Stn. DR04-A0511, 593 m, 6 specimens on coral debris and stones, a clump with 2 coralla, and 4 dead specimens broken and worn.-Stn. DR06A0511, 462 m, 14 specimens and clumps.-Stn. DR07A0511, $551 \mathrm{~m}$, several solitary specimens and clumps.

Remarks The material is formed by solitary specimens of stout appearance and small clumps perhaps due to autoepizoism or regeneration producing quasicolonies. This kind of growth is known in other species of the genus like $B$. cyathoides (de Pourtalès 1871) (see Cairns 2000, fig. 192).

The species has been collected within the depth range already known for this coral in the Bay of Biscay and nearby areas (380-1,150 m).

Balanophyllia thalassae is rarely cited in the literature and has a limited geographic distribution. According to Zibrowius (1980), it has been recorded from off the north, west, and south of the Iberian Peninsula and Madeira. It was collected recently from the Canary Islands by Brito and Ocaña (2004) and the Galicia Bank (Altuna 2013). All the records from the Bay of Biscay are from its southern sector, where it has its northern distributional limit. This coral may be locally abundant in certain areas of northern Spain, like Le Danois Bank (Zibrowius 1980, type material; Altuna 2013).

Dendrophyllia cornigera (Lamarck 1816) (Fig. 8i)

Dendrophyllia cornigera: Zibrowius 1980: 172, pl. 87, figs. A-I.-Monteiro Marques and Andrade 1981: 88
(listed).-Aguirrezabalaga et al. 1984: 94.-Altuna and García Carrascosa 1990: 56 (listed).-Ramil Blanco and Fernández Pulpeiro 1990: 28.-Álvarez Claudio 1993: 418 (listed)._Altuna Prados 1994a: 483._Altuna Prados 1994b: 55 (annex, listed).-Altuna Prados 1994c: 76, fig. 1.-Álvarez Claudio 1994: 467.-Altuna 1995: 92 (tab. 1, listed).-Paulmier 1997: 12, pl. 9, figs. 3-4, pl. 10, fig. 1.-Cairns and Chapman 2001: 35 (tab. 1, listed).-Castric-Fey et al. 2001: 90.-Brito and Ocaña 2004: 428, figs. 6, 11, 149, pl. 100, figs. A-F.Reveillaud et al. 2008: 322 (tab. 1, listed), fig. 4.Sánchez et al. 2009: 1180 (tab. 2, listed).-Altuna 2010: 21 (listed).- Louzao et al. 2010: tab. S1 (listed).Altuna 2012: 402 (tab. 2, listed).-Altuna 2013: 105 (tab. 2, listed).

Material examined V-2010: Stn. DR03-A0710, 143 m, 2 fragments. P-2011: Stn. DR01-A0511, $103 \mathrm{~m}, 3$ small colonies and fragments.-Stn. DR07-A0511, $551 \mathrm{~m}, 1$ dead fragment and 1 dead colony.-Stn. DR09-A0511, $86 \mathrm{~m}$, several subfossil fragments, much worn.

Remarks Most part of the material is fragmentary, much worn and subfossil. The depth observed in the canyon is consistent with previous data from the Bay of Biscay and nearby areas after a review of the literature (30-620 m). The shallowest records from the bay are from Finistère (see Castric-Fey 1996).

According to Zibrowius (1980), D. cornigera is known from Ireland to Cape Verde Islands, including the Azores archipelago and the Mediterranean Sea. It is widely distributed in the whole Bay of Biscay and nearby areas. Joubin (1922a, b) and Le Danois (1948) gave maps and precise locations of the $D$. cornigera banks in the bay, with additional data in Zibrowius (1980), Álvarez Claudio (1993, 1994), Altuna Prados (1994a, d), Altuna (1995), Castric-Fey (1996), Paulmier (1997), Castric-Fey et al. (2001), Reveillaud et al. (2008), Sánchez et al. (2009), and Louzao et al. (2010). It was previously known from the Avilés Canyon System (Álvarez Claudio 1994; Louzao et al. 2010).

Enallopsammia rostrata (de Pourtalès 1878) (Fig. 8a, b) Amphihelia rostrata de Pourtalès 1878: 204, pl. 1, figs. 4-5.

Enallopsammia rostrata: Zibrowius 1980: 201, pl. 105, figs. A-K, pl. 106, figs. A-C.- Zibrowius 1985: 314 (tab. 2, listed), 319.-Zibrowius and Grygier 1985: 131, figs. 48-50.- Ramil Blanco and Fernández Pulpeiro 1990: 29._Zibrowius and Gili 1990: 39, pl. 6A-F, 7A-F.-Álvarez Claudio 1993: 418 (listed).-Álvarez Claudio 1994: 467.-Cairns and Chapman 2001: 35 (tab. 1, listed).-Brito and Ocaña 2004: 436, pl. 103, figs. 


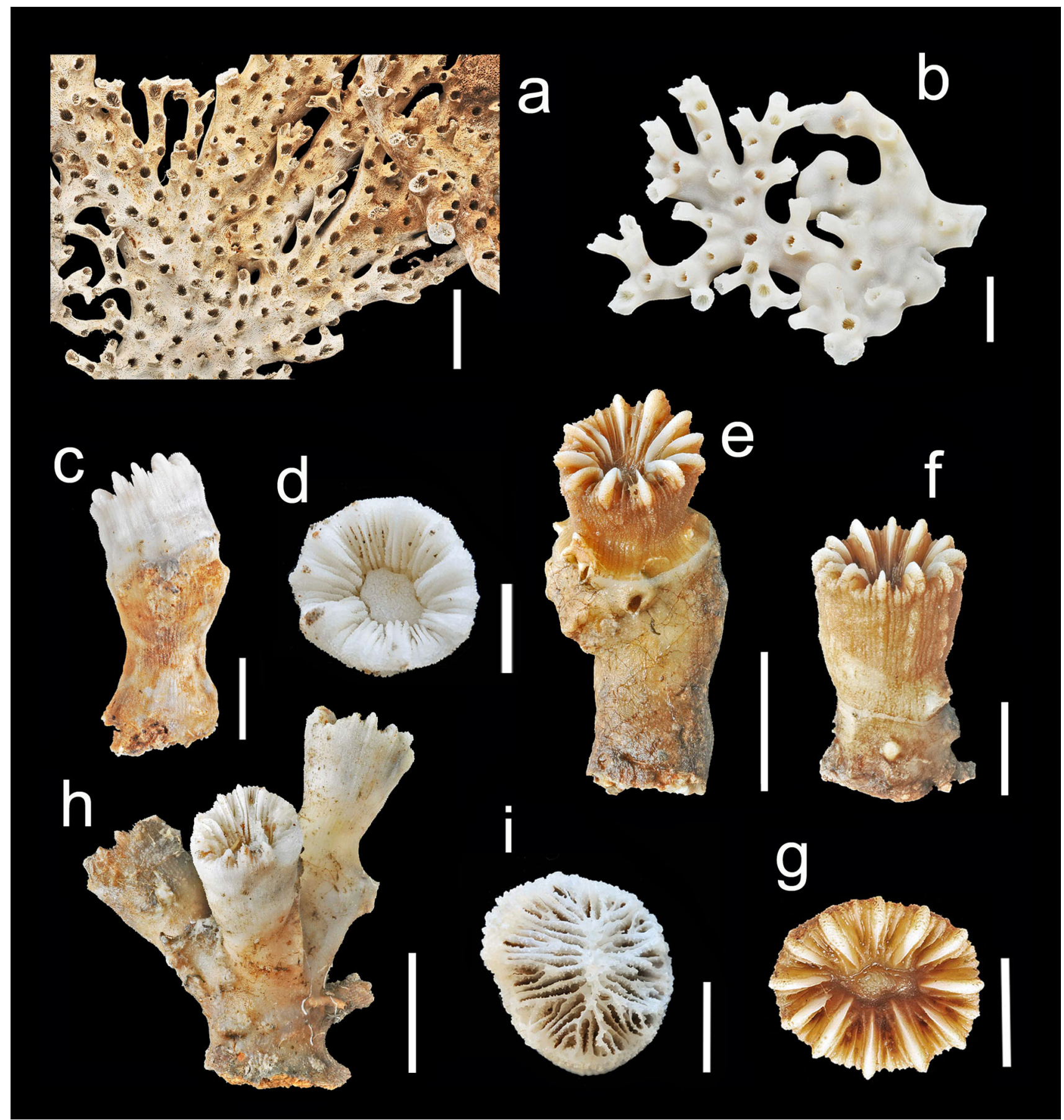

Fig. 8 Enallopsammia rostrata (de Pourtalès 1878). a Colony, Stn. DR17-A0710 (V-2010); note a gall above right. b Colony, Stn. G07A0511 (P-2011). Balanophyllia thalassae Zibrowius 1980. c Corallum in side view, Stn. DR07-A0511, (P-2011). d Calice, Stn. DR06A0511 (P-2011). e, f Two specimens, Stn. DR18-A0511 (P-2011). g Calice from specimen $\mathbf{f}$. h A quasicolony with three corallites, Stn. DR07-A0511 (P-2011). Dendrophyllia cornigera (Lamarck 1816), Stn. DR03-A0511 (P-2011). i Calice. Scale bar $\mathbf{a}, \mathbf{e}, \mathbf{h}=20 \mathrm{~mm} ; \mathbf{b}$, $\mathbf{c}, \mathbf{f}=15 \mathrm{~mm} ; \mathbf{d}=8 \mathrm{~mm} ; \mathbf{g}, \mathbf{i}=5 \mathrm{~mm}$

Material examined P-2010: Stn. DR22-A0410, 2,291 m, several colonies and fragments.-V-2010: Stn. DR15A0710, 1,228 m, 1 big-sized dead flabelliform colony, and fragments. P-2011: Stn. G06-A0511, 1,244 m, 1 dead 
fragment, worn.-Stn. G07-A0511, $990 \mathrm{~m}$, several bigsized colonies.

Remarks This species was collected in the canyon at a depth range of 1,228-2,291 m. Station DR22-A0410 $(2,291 \mathrm{~m}$, live specimens) is the deepest for the species according to the range of $110-2,165 \mathrm{~m}$ given by Cairns (2010). In the Bay of Biscay and nearby areas, it was known from 915 to 1,980 m depth (Zibrowius 1980, 1985; Álvarez Claudio 1994; Louzao et al. 2010).

Some colonies from Stn. DR15-A0710 and Stn. G07A0511 have ascothoracid galls (see Zibrowius and Grygier 1985; Zibrowius and Gili 1990).

Enallopsammia rostrata is known from the Celtic Sea, the Bay of Biscay, Portugal, Madeira and Azores archipelagos, Morocco, Western Sahara, the Guinea Gulf and Namibia (see Zibrowius 1980; Zibrowius and Gili 1990). It was recently collected from the Canary Islands (Brito and Ocaña 2004). In the Bay of Biscay, the species is known since a long time ago. Although records are not abundant, the species has been collected from the northern (Zibrowius 1980) and southern sectors (Milne Edwards 1882; Gourret 1906; Zibrowius 1980, 1985; Zibrowius and Grygier 1985), including the Avilés Canyon System (Álvarez Claudio 1993, 1994; Louzao et al. 2010).

\section{Eguchipsammia cornucopia (de Pourtalès 1871)}

(Fig. 9a-g)

Dendrophyllia cornucopia: Zibrowius 1980: 175, pl. 88, figs. A-L.

Eguchipsammia gaditana: Altuna 2012: 402 (tab. 2, listed), fig. 1.16.

Eguchipsammia cornucopia: Altuna 2013: 119, fig. 5H-

J, tabs. 1-3 (listed).

Material examined P-2010: Stn. DR18-A0410, 767 m, several colonies, single specimens and fragments, all dead, much worn.-P-2011: Stn. DR04-A0511, 593 m, 2 dead specimens, worn.

Description Corallum unattached, solitary or forming small sparsely branched colonies, rarely straight, more commonly irregularly bent or even scolecoid, tapering basally. Colonies up to $65.0 \mathrm{~mm}$ in height, with a slender axial corallite and a few secondary and tertiary corallites budding at irregular intervals. Secondary coralla born extratentacularly, almost perpendicular to the main corallite wall, although with growth they curve upward paralleling it. Coenosteum porous near the calices. Wall costate, with $\mathrm{C} 1-\mathrm{C} 2$ distinctly ridged, and $\mathrm{C} 3-\mathrm{C} 4$ progressively less ridged. Costae bearing minute granules and spiniform processes. Calices almost round to slightly elliptical, those of axial corallite up to $\mathrm{GCD}=8.0 \mathrm{~mm}$ and $\mathrm{LCD}=7.0 \mathrm{~mm}$, others smaller, with secondary calices up to $\mathrm{GCD}=7.7 \mathrm{~mm}$ and $\mathrm{LCD}=7.0 \mathrm{~mm}$, and tertiary up to $\mathrm{GCD}=4.7 \mathrm{~mm}$ and $\mathrm{LCD}=4.1 \mathrm{~mm}$. Septa up to 48 arranged in 4 cycles and 6 systems according to the formula $\mathrm{S} 1 \geq \mathrm{S} 2>\mathrm{S} 3<\mathrm{S} 4$, and mostly following Pourtalès Plan. S1 more exsert than S2, these more than S3 and these, equally exsert than S4. S1 extending slightly farther toward the columella than $\mathrm{S} 2$, these much more than $\mathrm{S} 3$, and $\mathrm{S} 3$ shorter than S4. S4 joint in front of S3 forming a P3. Septal faces and pali with abundant and apparent pointed granules. Columella round to elliptical, spongy, located in the center of a shallow fossa.

Remarks The material consists in small-sized dead and eroded colonies and solitary corallites covered with a likely manganese coating. Most specimens are irregularly bent, and calices renovations are common. Although septa can be up to 48 , their number in larger corallites is frequently 36. Due to their small size with GCD up to $9.0 \mathrm{~mm}$ normally smaller if compared with other colonies from $E$. cornucopia from the Bay of Biscay (see Altuna 2013), and the low number of septa, the material was erroneously identified as $E$. gaditana in a preliminary report (Altuna 2012). Access to more material and the paper by Cairns (2000: 169), in which he mentions small-sized Caribbean colonies of E. cornucopia with GCD $=8-9 \mathrm{~mm}$ and rarely more than 48 septa, make us modify the former identification.

Depth of collection (593-767 m) agrees with the depth distribution of the species in the Bay of Biscay and nearby areas $(330-960 \mathrm{~m})$. This is an amphi-Atlantic coral scarcely recorded in the eastern Atlantic, and recently redescribed from material collected in Le Danois Bank (Altuna 2013). It is known from the northern and southern sectors of the bay, including the Avilés Canyon System (Zibrowius et al. 1975; Zibrowius 1980; Álvarez Claudio 1993, 1994; Louzao et al. 2010).

\section{Unidentified material (Fig. 9h-j)}

P-2010: Stn. DR24-A0410, 1,533 m, 4 fragments, rolled, dead.-V-2010: Stn. DR05-A0710, $128 \mathrm{~m}, 1 \mathrm{~min}$, young, attached solitary Caryophylliid with $\mathrm{H}=2.0 \mathrm{~mm}$ and $\mathrm{GCD}=\mathrm{LCD}=2.6 \mathrm{~mm}, 26$ septa arranged hexamerally (S1 > S2 > S3), one P2, and a columella formed by a few twisted ribbons; the specimens are smashed.-P-2011: Stn. DR04-A0511, 593 m, 3 small stones with pedicels, no calices.-Stn. DR05-A0511, $908 \mathrm{~m}, 1$ specimen $2.3 \mathrm{~mm}$ in GCD on coral debris, with 24 septa in three complete cycles $\mathrm{S} 1>\mathrm{S} 2>\mathrm{S} 3$ and a small columella (Fig. 9j); a likely Caryophylliid.-P-2012: Stn. ROV6-A0412, $1,161 \mathrm{~m}, 2$ small attached specimens with largest being $6.5 \mathrm{~mm}$ in height and GCD $=\mathrm{LCD}=2.4 \mathrm{~mm}$. Fossa is very deep, and septa are 24 in three cycles S1-S3; a columella is lacking (Fig. 9h-i). The specimen is a likely 


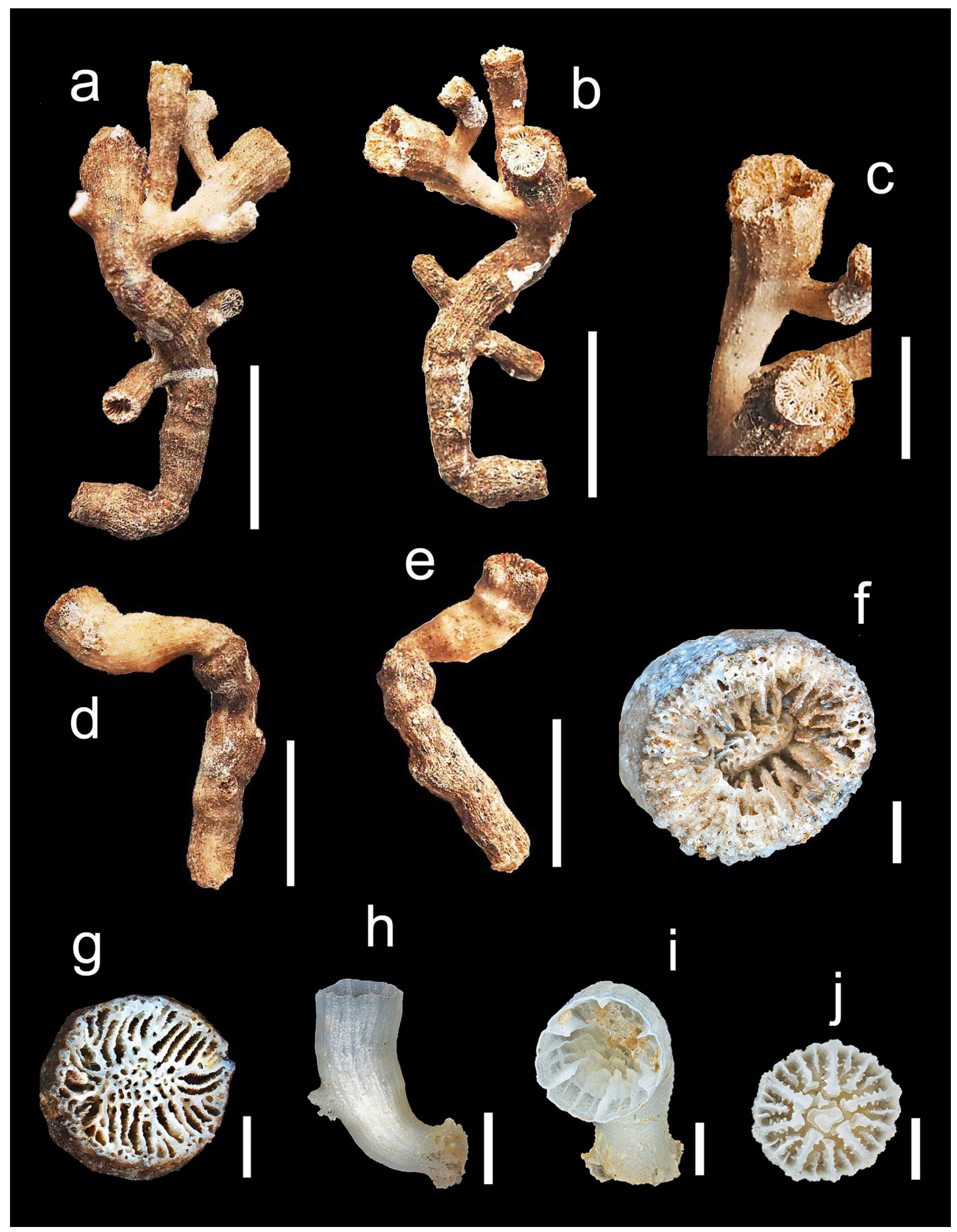


४Fig. 9 Eguchipsammia cornucopia (de Pourtalès 1871), Stn. DR18A0410 (P-2010). a, b Colony, two views of the same specimen. c Detail of the same colony. d, e Two views of the same solitary specimen. f, $\mathbf{g}$ Calices from other specimens. h, i Unidentified specimen from Sta. ROV6-A0412 (P-2012). j Unidentified specimen from Stn. DR05-A0511. Scale bar $\mathbf{a}, \mathbf{b}, \mathbf{d}, \mathbf{e}=15 \mathrm{~mm} ; \mathbf{c}=10 \mathrm{~mm}$; $\mathbf{f}-\mathbf{h}=2 \mathrm{~mm} ; \mathbf{i}, \mathbf{j}=1 \mathrm{~mm}$

juvenile Desmophyllum (see Zibrowius 1980, pl. 62, fig. $\mathrm{H})$.

\section{Discussion}

The Scleractinia of the Avilés Canyon System were studied by Álvarez Claudio (1993, 1994) and Louzao et al. (2010). The canyon was also surveyed in the ECOMARG 2009 expedition (IEO), but only four common species that cooccurred at $500 \mathrm{~m}$ depth were dredged (Caryophyllia calveri, Desmophyllum cristagalli, Lophelia pertusa, Madrepora oculata, Altuna 2013). As a result of these studies, 18 species were known before the INDEMARES AVILÉS 2010-2012 expeditions (Table 3). During these expeditions, 28 scleractinian species have been collected at a depth interval of 55-2,291 m (Tables 1, 2), with 13 being new for the canyon system. Thirty-one species occur in the whole system including the shelf nearby (Table 3). Deltocyathus eccentricus and Flabellum chunii collected in this study are northernmost and new records for the Bay of Biscay. Additionally, Aulocyathus atlanticus, Fungiacyathus fragilis, and Monomyces pygmaea are rarely recorded corals in the northeast Atlantic. Three species, Caryopyllia cyathus (Ellis and Solander 1786), Enallopsammia marenzelleri Zibrowius 1973, and Stenocyathus vermiformis (de Pourtalès 1868) are known from the canyon and were not collected during the INDEMARES AVILÉS surveys.

The biodiversity in the canyon is here considered high if compared to the whole fauna of the Bay of Biscay and nearby areas. Forty-four species were known from this fauna until the present study including the littoral and deepsea scleractinians (Zibrowius 1980; Álvarez Claudio 1994; Altuna 1995, 2010, 2013; Reveillaud et al. 2008). With the new records, 46 are the species known from the Bay of Biscay, and 45 those of its southern sector ("I" sector from Zibrowius 1980). The scleractinian fauna of this sector is one of the most diversified in the northeast Atlantic including the Mediterranean Sea and comprises 41 deepsea corals, i.e., those occurring below a depth of $50 \mathrm{~m}$ (see Cairns 2007: 313). Only four species have not been already collected below this depth: Balanophyllia regia Gosse 1860, Caryophyllia inornata, Hoplangia durotrix Gosse 1860, and Polycyathus muellerae (Abel 1959).
Although all the species collected herein were already known from the northeastern Atlantic, the number of taxa identified from the canyon is notable if compared with the whole fauna of the Bay of Biscay (67\% of it). This could be explained by the great biological production of the canyon system (see Sánchez et al. 2008, 2009, 2012; Sánchez 2009), by the intensive sampling, by the wide bathymetric range studied $(55-2,291 \mathrm{~m})$, and by the biocenological complexity of the canyon, with different soft and hard-bottom habitats. From these, deepwater coral banks of the La Gaviera Canyon are noteworthy by their extension and good preservation (see Sánchez et al. 2014). The three main bank builders of the Bay of Biscay ( $L$. pertusa, M. oculata, and Solenosmilia variabilis) occur in the canyon and were collected in the INDEMARES surveys. Tabulating the number of species occurring in each $100 \mathrm{~m}$ interval of the canyon system, L. pertusa and $M$. oculata thrive in the canyon system between the 300-400-m and 1,100-1,200-m, and the 300-400-m and 1,600-1,700-m depth intervals, respectively (Table 4). Additionally, two other large colonial species, Enallopsammia rostrata and $S$. variabilis, co-occur with them at certain depth intervals (900-1,200 m) but all four have not been collected together (Tables 2, 4).

In the whole study area, 17 species occur on hard bottoms, and at least seven of them use L. pertusa and $M$. oculata as substrate (A. atlanticus, Caryophyllia atlantica, C. calveri, C. sarsiae, D. cristagalli, Javania cailleti, Balanophyllia thalassae). As usual, L. pertusa and M. oculata intermingle, growing on each other. Some species were collected on stones, as the big-sized colonial species $S$. variabilis and E. rostrata, which may be locally abundant. Both are unusually reported from the Bay of Biscay and were collected alive at the deepest station that yielded scleractinia (Stn. DR22-A0410, P-2010, 2,291 m). Moreover, 11 species are proper of soft substrata $(F$. fragilis, Caryophyllia seguenzae, D. eccentricus, D. moseleyi, Premocyathus cornuformis, Stephanocyathus moseleyanus, S. nobilis, Flabellum alabastrum, F. chunii, F. macandrewi, Eguchipsammia cornucopia). None of them was collected in abundance, and presumably did not reach high densities of population.

Most species are solitary $(22,78 \%)$, and one of the six colonials, E. cornucopia, is unattached. Lophelia pertusa (24 stations), M. oculata (22 stations), and D. cristagalli (19 stations) were the most abundant species, as occurs in bathyal hard-bottom of the Bay of Biscay. The latter is a coral commonly associated with $L$. pertusa and $M$. oculata in the northeast Atlantic, and live specimens of the three species co-occur at 9 stations of the canyon between 649 and $908 \mathrm{~m}$ depth (Table 2). Besides, live colonies of $L$. pertusa and $M$. oculata co-occurred in other five stations 
Table 3 Species (31) that are known in the Avilés Canyon System and the near continental shelf, and sources

\begin{tabular}{|c|c|}
\hline Species & Sources \\
\hline Aulocyathus atlanticus Zibrowius & 5 \\
\hline Balanophyllia thalassae Zibrowius & 5 \\
\hline Caryophyllia abyssorum Duncan & $1,2,3,5$ \\
\hline Caryophyllia atlantica (Duncan) & 5 \\
\hline Caryophyllia calveri Duncan & 4,5 \\
\hline Caryophyllia cyathus (Ellis and Solander) & 1 (cf.), 3 \\
\hline Caryophyllia sarsiae Zibrowius & 5 \\
\hline Caryophyllia seguenzae Duncan & 5 \\
\hline Caryophyllia smithii Stokes and Broderip & $1,2,3,5$ \\
\hline Deltocyathus eccentricus Cairns & 5 \\
\hline Deltocyathus moseleyi Cairns & $1,2,3,5$ \\
\hline Dendrophyllia cornigera (Lamarck) & $1,2,3,5$ \\
\hline Desmophyllum cristagalli Milne Edwards and Haime & $1,2,4,5$ \\
\hline Eguchipsammia cornucopia (de Pourtalès) & $1,2,3,5$ \\
\hline Enallopsammia marenzelleri Zibrowius & 1,3 \\
\hline Enallopsammia rostrata (de Pourtalès) & $1,2,3,5$ \\
\hline Flabellum alabastrum Moseley & $1,2,3,5$ \\
\hline Flabellum chunii Marenzeller & 5 \\
\hline Flabellum macandrewi Gray & 5 \\
\hline Fungiacyathus fragilis G.O. Sars & 5 \\
\hline Javania cailleti (Duchassaing and Michellotti) & 5 \\
\hline Lophelia pertusa (L.) & $1,2,3,4,5$ \\
\hline Madrepora oculata $\mathrm{L}$. & $1,2,3,4,5$ \\
\hline Monomyces pygmaea (Risso) & 5 \\
\hline Paracyathus pulchellus (Philippi) & $1,2,3,5$ \\
\hline Premocyathus cornuformis (de Pourtalès) & $1,2,3,5$ \\
\hline Solenosmilia variabilis Duncan & 5 \\
\hline Stenocyathus vermiformis (de Pourtalès) & $1,2,3$ \\
\hline Stephanocyathus moseleyanus (Sclater) & $1,2,3,5$ \\
\hline Stephanocyathus nobilis (Moseley) & 5 \\
\hline Vaughanella concinna Gravier & 2,5 \\
\hline Total & 31 \\
\hline
\end{tabular}

(1) Álvarez Claudio (1993). (2) Álvarez Claudio (1994). (3) Louzao et al. (2010). (4) Altuna (2013). (5) Present paper and Altuna (2012) (INDEMARES AVILÉS project). No additional material was collected by Louzao et al. (2010), whose species list was a compilation of records from previous authors

between 342 and $790 \mathrm{~m}$ depth. Ten species were obtained in a unique station.

The highest number of species $(8$, from three of them only dead specimens) was collected in Stn. DR03-A0410 (P-2010, $893 \mathrm{~m})$ at the La Gaviera Canyon. Most of them are hard-bottom species associated with the coral bank framework, either as constructors like $L$. pertusa and $M$. oculata or using these as substrate (A. atlanticus, Caryophyllia abyssorum, $C$. sarsiae, D. cristagalli). There are three stations with seven species (Table 1), three of them corresponding also to the La Gaviera Canyon. Only in one of them (Stn. DR04-A0410, P-2010, $700 \mathrm{~m}$ ) were all the species collected alive. In all these stations, there are two bank builders (L. pertusa, M. oculata). Conversely, in Stn. V03-A0511 (P-2011, 1,473 m, 7 species collected, 3 dead), six species are unattached with varied morphologies adapted to soft substrates (discoid, patellate, flabelliform). The two most interesting species $F$. chunii and D. eccentricus were collected therein. In most stations, there are only one (14 stations) or two species (10 stations).

Most of the species are eurybathial and live in wide depth ranges in their distribution areas. The widest bathymetric range in the study area corresponds to $D$. cristagalli $(1,740 \mathrm{~m})$, followed by $S$. variabilis $(1,524 \mathrm{~m}$, Table $2 \mathrm{C})$. Live specimens of both species co-occurred at the deepest station sampled (P-2010, Stn. DR22-A0410, 2,291 m) with $J$. cailleti (dead specimens) and E. rostrata. Desmophyllum cristagalli occurs in $78.3 \%$ of the depth intervals selected (Table 4). Solenosmilia variabilis $(69.5 \%)$ and E. rostrata $(61 \%)$ are also widely distributed species along the depth gradient, and 10 species were collected only in one interval.

Most species were collected within the bathymetric ranges already known for the Bay of Biscay and nearby seas, although there are new depth records for the Bay of Biscay (Table 2), or for the species. Eleven corals were recorded out of their previously known bathymetric ranges in the Bay of Biscay and nearby areas, either at shallower depths (C. abyssorum (dead specimen), C. sarsiae, $M$. pygmaea, $S$. nobilis), or deeper depths (C. atlantica, $C$. sarsiae, $C$. smithii (dead specimen), E. rostrata, $F$. fragilis (dead specimen), J. cailleti (dead specimen), L. pertusa (dead specimen), S. variabilis). According to depth ranges given by Cairns (2010), six species (C. seguenzae, $C$. smithii (dead specimen), E. rostrata, $F$. chunii (dead specimen), J. cailleti (dead specimen), S. variabilis) occur at deeper depths than previously known. On this respect, a great caution was observed during sampling and manipulation on board. However, Zibrowius (1985: 322) has suggested that the uncommon depths at which some species are collected in bathyal sampling may be invalid due to confusions. Besides, some zones of the axis of the Avilés Canyon System may be covered by detritic materials from the platform or the slope that are drained to the abyssal plain. Hence, some dead specimens discovered herein at unusual depths might have been transferred from upper levels of the canyon system.

Examples of curves of zooxanthellate Scleractinia along a depth gradient have been traced for coastal areas of tropical (Fricke and Schuhmacher 1983; Huston 1985) and subtropical seas (Brook 1999), and the high species richness at shallow depth in these ecosystems is a topic that does not need further discussion. Nevertheless, conclusions are different if only azooxanthellate species are considered, 
Table 4 Species occurring in every 100-m depth interval of the Avilés Canyon System and the nearby continental shelf (55-2,291 m)

\begin{tabular}{|c|c|c|c|c|c|c|c|c|c|c|c|c|c|c|c|c|c|c|c|c|c|c|c|c|c|c|c|c|}
\hline 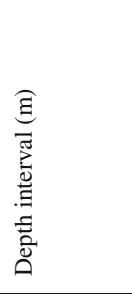 & 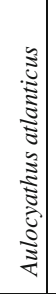 & 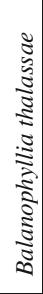 & 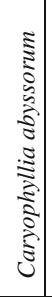 & 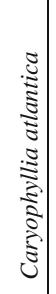 & 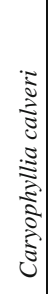 & 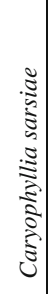 &  & 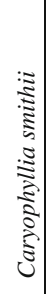 & 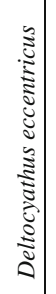 & 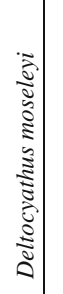 & 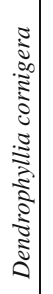 &  & 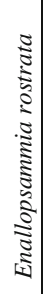 & 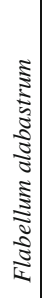 & 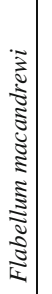 & 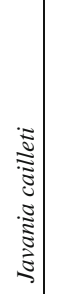 & 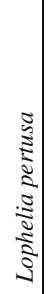 &  & 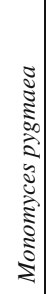 & 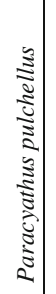 & 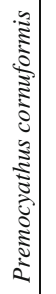 & 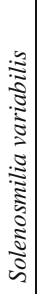 & 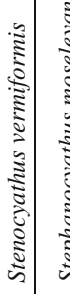 &  & 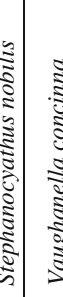 & 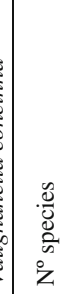 & 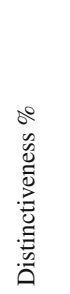 & 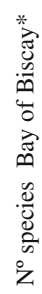 \\
\hline $50-100$ & & & & & & & & & & & E & & & & & & & & U & & & & & & & 2 & 0.0 & - \\
\hline $100-200$ & & & & & & & & U & & & U & & & & & & & & & T & & & & & & 3 & 75.0 & 1 \\
\hline $200-300$ & & & & & & & & प & & & 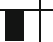 & & & & & & & & & & & & & & & 2 & 33.3 & 5 \\
\hline $300-400$ & & & & & & & & 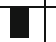 & & & U & & & & & & U & U & & & & & & & & 4 & 50.0 & 6 \\
\hline $400-500$ & & U & & & & & & & & & E & & & & & & U & 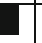 & & & & & & & & 4 & 40.0 & 9 \\
\hline $500-600$ & & ] & & & & & & & & U & U & U & & & & & t & U & & & & & & & & 6 & 33.3 & 13 \\
\hline $600-700$ & & U & & & U & U & & & & U & U & U & & & & & U & E & & & & & & & & 8 & 25.0 & 11 \\
\hline $700-800$ & & U & U & & U & U & & & & U & U & U & & & & & U & U & & & & 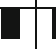 & U & & & 11 & 27.3 & 13 \\
\hline $800-900$ & U & & U & & & U & & & & U & U & U & & & E & & U & U & & & & 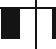 & E & & & 11 & 35.7 & 15 \\
\hline 900-1000 & & & U & & & U & & & & & & U & $\square$ & & & & U & U & & & & $\square$ & & & U & 8 & 53.8 & 14 \\
\hline $1000-1100$ & & & U & & & U & & & & & & U & U & & & & U & U & & & E & 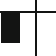 & & & U & 9 & 11.1 & 19 \\
\hline $1100-1200$ & & & D & & & E & & & & & & D & U & & & & U & 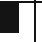 & & & & प & & & U & 8 & 11.1 & 17 \\
\hline $1200-1300$ & & & & & & U & & & & & & U & E & & & & & E & & & & $\square$ & & 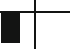 & 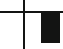 & 7 & 33.3 & 17 \\
\hline $1300-1400$ & & & & & & I & & & & & & E & U & & & 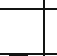 & & D & & & & $\square$ & & 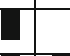 & 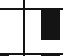 & 7 & 0.0 & 16 \\
\hline $1400-1500$ & & & & & & U & U & & U & & & U & U & & & U & & U & & & & 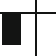 & & 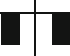 & D & 11 & 36.4 & 16 \\
\hline $1500-1600$ & & & & $\boldsymbol{U}$ & & ש & & & & & & 0 & U & & & U & & $\square$ & & & & 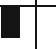 & & & 0 & 8 & 41.7 & 15 \\
\hline $1600-1700$ & & & & & & & & & & & & 7 & U & U & & T & & U & & & & 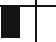 & & & t & 7 & 33.3 & 14 \\
\hline 1700-1800 & & & & & & & & & & & & U & U & & & & & & & & & $\square$ & & & & 3 & 57.1 & 15 \\
\hline $1800-1900$ & & & & & & & & & & & & U & U & & & & & & & & & $\square$ & & & & 3 & 0.0 & 14 \\
\hline 1900-2000 & & & & & & & & & & & & U & U & & & & & & & & & $\square$ & & & & 3 & 0.0 & 16 \\
\hline $2000-2100$ & & & & & & & & & & & & U & U & & & & & & & & & $\square$ & & & & 3 & 0.0 & 12 \\
\hline $2100-2200$ & & & & & & & & & & & & U & U & & & & & & & & & $\square$ & & & & 3 & 0.0 & 12 \\
\hline $2200-2300$ & & & & & & & & & & & & $\boldsymbol{\theta}$ & U & & & & & & & & & $\square$ & & & & 3 & 0.0 & 12 \\
\hline $\begin{array}{l}\text { Depth } \\
\text { interval } \\
\text { (m) }\end{array}$ & $\stackrel{\infty}{\infty}$ &  & $\begin{array}{l}\infty \\
\stackrel{\infty}{*} \\
0 \\
0\end{array}$ & חֶ & 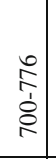 & 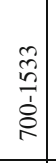 & 守 & 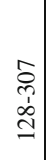 & 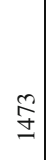 & 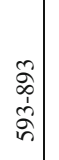 & $\begin{array}{l}\text { क } \\
\stackrel{1}{1} \\
\text { in }\end{array}$ & $\begin{array}{l}\bar{a} \\
\bar{i} \\
\overline{1} \\
i \\
i\end{array}$ & $\begin{array}{l}\overline{\hat{\lambda}} \\
\hat{1} \\
\vdots \\
\alpha\end{array}$ & : & $\stackrel{\infty}{\infty}$ & 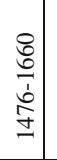 & 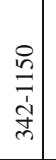 & $\begin{array}{l}\text { : } \\
\text { ì } \\
\text { जे }\end{array}$ & in & 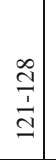 & & 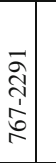 & 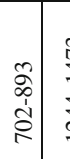 & & 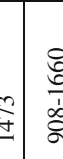 & - & - & - \\
\hline $\begin{array}{c}\text { Percentage } \\
\%\end{array}$ & $\stackrel{m}{+}$ & \pm & $\dot{\mathrm{i}}$ & $\stackrel{m}{+}$ & $\stackrel{\infty}{\infty}$ & q & $q$ & $\stackrel{\sim}{-}$ & $\stackrel{m}{+}$ & $\stackrel{+}{=}$ & ले & 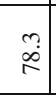 & $\begin{array}{l}0 \\
0\end{array}$ & $\stackrel{m}{+}$ & $\stackrel{m}{+}$ & $\stackrel{0}{\rightarrow}$ & $\overline{8}$ & 6 & $\stackrel{?}{+}$ & $\stackrel{?}{+}$ & $\stackrel{?}{+}$ & 8 & \begin{tabular}{l|l}
\multirow{\infty}{*}{} & $:$ \\
\end{tabular} & \begin{tabular}{c|c}
$\stackrel{0}{-}$ & 9 \\
\end{tabular} & \begin{tabular}{c|c}
$g$ & 0 \\
$g$ & $m$
\end{tabular} & - & - & - \\
\hline
\end{tabular}

Data from Álvarez Claudio (1993, 1994), Altuna (2013), and the present study. Depth records were compiled for every species, and the bathymetric range given as the interval between shallowest and deepest records. Distinctiveness between intervals was calculated according to Menzies et al. (1973): D \% = (T-Tc) 100/T ( $T c$ total taxa in common between any two intervals, $T$ total of species in both intervals, $D$ percentage of distinctiveness). * According to Reveillaud et al. (2008), percentage $=$ number of intervals in which the species occurs expressed as $\%$ of the 23 intervals considered in the analysis. Only specimens collected alive have been taken in consideration

which are more abundant at bathyal depths. In the Bay of Biscay, Reveillaud et al. (2008) provided bathymetric ranges for 34 species, with highest species richness in the 1,000-1,100-m depth interval (Table 4). In the present study, a curve of biodiversity at increasing depth was traced for all the species collected alive in the canyon system adding data from Álvarez Claudio (1994) and Altuna (2013) (Fig. 10). It represents an idealized transect of the canyon's fauna covering all type of communities, in which the species occurring in every 100-m depth interval 
Fig. 10 Number of species occurring at increasing depth in every $100-\mathrm{m}$ depth interval of the Avilés Canyon System and the nearby continental shelf. Depth records were compiled for every species, and the bathymetric range considered as the interval between shallowest and deepest records. Only specimens collected alive have been taken in consideration. Data were taken from Álvarez Claudio (1994), Altuna (2013) and the present study

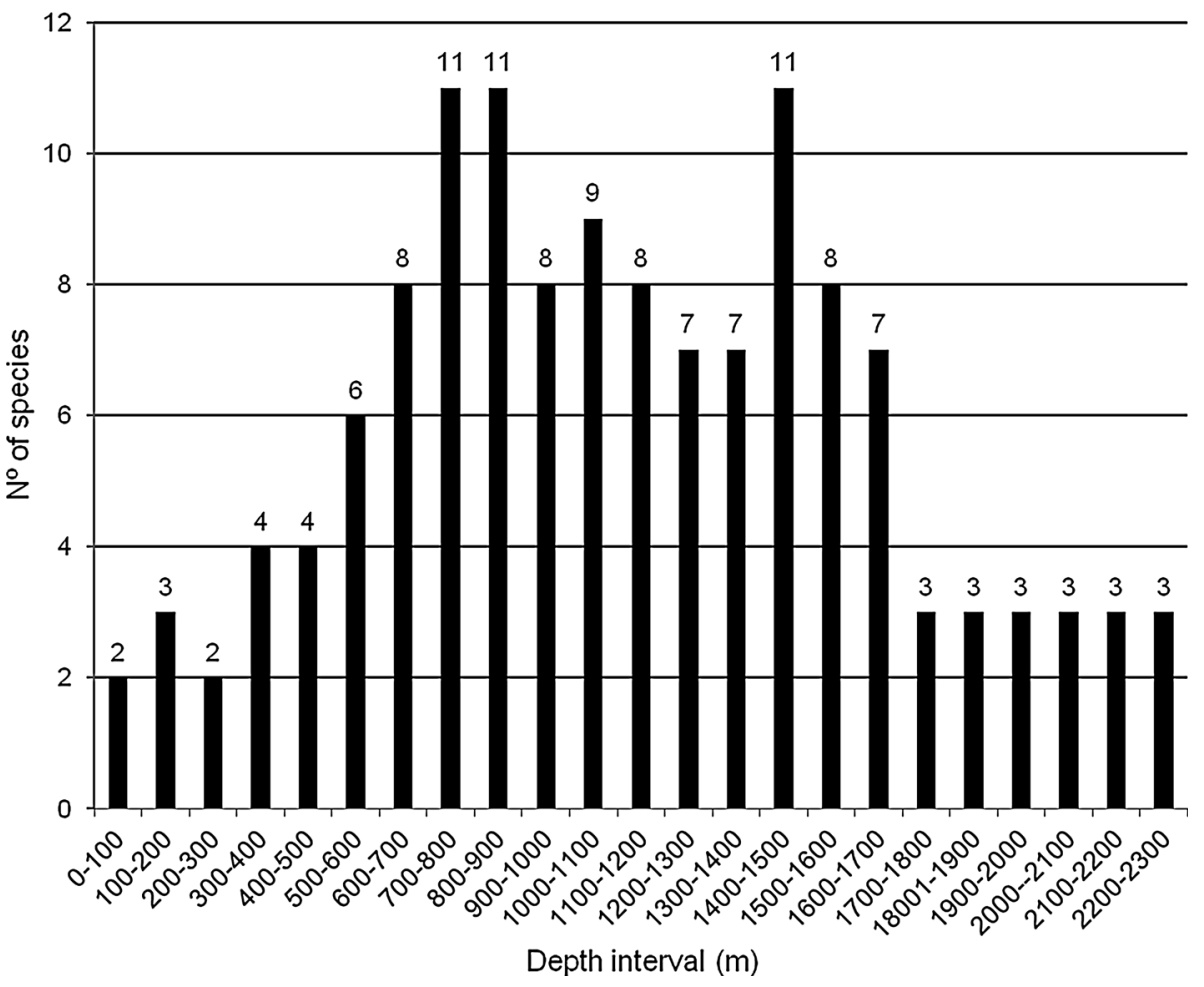

were tabulated. It is a synthesis of the whole fauna avoiding the variation in species richness that occurs between stations and regions in the deep-sea. Four species occur in the area of shelf studied (50-200 m depth), mainly in a community here called "Circalittoral rock dominated by Phakellia ventilabrum and Dendrophyllia cornigera." Two of them, C. smithii and D. cornigera, thrive beyond the shelf in the upper slope. At increasing depth on the slope, there is a meaningful and gentle enhance in the number of species, with major gain in the 700-800-m depth interval (3 new species, $C$. abyssorum, $S$. variabilis, $S$. vermiformis). Highest biodiversity is in the 700-800, 800-900, and 1,400-1,500-m depth intervals (11 species, $42 \%$ of all the species collected alive). Drop in biodiversity between the 800-900-m depth (11 species) and the 1,400-1,500-m depth when it recovers (11 species) is very likely attributable to sampling or to material that was collected only dead. Highest distinctiveness occurs between the 1,600-1,700-m and the 1,700-1,800-m depth intervals $(57 \%)$, explained by the loss of four species in the latter ( $F$. alabastrum, J. cailleti, M. oculata, Vaughanella concinna). Only three eurybathic corals persist beyond this depth, namely $D$. cristagalli, E. rostrata, and $S$. variabilis. These are the unique species that were collected alive between the 1,700-1,800 $\mathrm{m}$ interval and the deepest station sampled $(2,291 \mathrm{~m})$. In the Avilés Canyon System, azooxanthellate scleractinian corals reach their highest biodiversity in the bathyal slope, agreeing with the general picture of these animals that, worldwide, most commonly live between 200 and 1,000 m depth (Cairns 2004, 2007). There are five species that, in being collected only dead, were not included when tracing the curve. Additional sampling in the system could certainly add new live species to the depth intervals, but, although sampling is uneven in the whole column, we consider that new data hardly could modify substantially the shape of the curve.

Acknowledgments $\mathrm{We}$ are indebted to Alberto Serrano, Javier Cristobo, and Francisco Sánchez for giving us the opportunity of studying the material and for their help with the samples. Cooperation of Helmut Zibrowius clearing some taxonomic doubts is also acknowledged. Thanks are also due to an anonymous referee for the review of our manuscript. This study was funded by the European Community contract INDEMARES-LIFE project (07/NAT/E/ 000732).

\section{References}

Acosta Yepes J, Sánchez Delgado F (2010) INDEMARES-AVILÉS 0410. Plan de campaña, Gobierno de España, Ministerio de Medio Ambiente Rural y Marino, Madrid

Aguirrezabalaga F, Altuna Á, Borja A, Feliú J, García Carrascosa AM, Romero A, San Vicente C, Torres Gómez J, Uriz MJ, Ibáñez M (1984) Contribución al conocimiento de la fauna marina de la Costa Vasca II. Lurralde 7:83-133

Aguirrezabalaga F, Altuna Á, Marruedo J, Miner A, Peña J, Romero A, San Juan R, San Vicente C, Serrano A, Ibáñez M (1988) Contribución al conocimiento de la fauna marina de la Costa Vasca VI. Lurralde 11:217-265

Altuna Á (1995) El orden Scleractinia (Cnidaria, Anthozoa) en la costa vasca (Golfo de Vizcaya); especies batiales de la fosa de Capbretón. Munibe 47:85-96 
Altuna Á (2010) Listado de los cnidarios bentónicos (phylum Cnidaria) del Golfo de Vizcaya y zonas próximas (Atlántico $\mathrm{NE})\left(42^{\circ} \mathrm{N}\right.$ a $48^{\circ} 30^{\prime} \mathrm{N}$ y $\left.10^{\circ} \mathrm{W}\right)$. Proyecto Fauna Ibérica, Museo Nacional de Ciencias Naturales, Madrid

Altuna Á (2012) Escleractinias (Cnidaria: Anthozoa: Scleractinia) obtenidas en las campañas INDEMARES 2010-2011 en el Cañón de Avilés (Golfo de Vizcaya, Atlántico NE). RIM 19:399-403

Altuna Á (2013) Scleractinia (Cnidaria: Anthozoa) from ECOMARG 2003, 2008 and 2009 expeditions to bathyal waters off north and northwest Spain (north-east Atlantic). Zootaxa 3641:101-128

Altuna Á, García Carrascosa AM (1990) Euskal Herriko medusa, anemona eta koralak. Kriselu, San Sebastián

Altuna Prados Á (1993) Notas sobre los cnidarios bentónicos de la costa vasca I.-Mitrocomium cirratum Haeckel, 1879 y Halecium liouvillei Billard, 1934. Kobie 21:43-54

Altuna Prados Á (1994a) Estudio faunístico, ecológico y biogeográfico de los cnidarios bentónicos de la costa vasca. PhD Thesis. University of Navarra, pp 769

Altuna Prados Á (1994b) Observaciones biogeográficas sobre los cnidarios bentónicos de la costa vasca. Kobie 22:41-57

Altuna Prados Á (1994c) El orden Scleractinia (Cnidaria: Anthozoa) en la costa vasca; consideraciones generales y especies litorales. Kobie 22:67-82

Altuna Á, Sinniger F, Aldrey JM (2010) Occurrence of Savalia savaglia (Anthozoa: Zoantharia) in the Ría de Arousa (Galicia, north-western Spain, north-eastern Atlantic). Mar Biodivers Rec 3:1-5. doi:10.1017/S1755267210000965

Álvarez Claudio C (1993) Hidrozoos bentónicos y catálogo de antozoos de la plataforma y talud continentales de la costa central de Asturias. PhD Thesis. University of Oviedo, pp 458

Álvarez Claudio C (1994) Deep-water Scleractinia (Cnidaria: Anthozoa) from southern Biscay Bay. Cah Biol Mar 35:461-469

Brito A, Ocaña O (2004) Corales de las Islas Canarias. Antozoos con esqueleto de los fondos litorales y profundos. Francisco Lemus, La Laguna

Brook FJ (1999) The coastal scleractinian coral fauna of the Kermadec Islands, southwestern Pacific Ocean. J R Soc NZ 29:435-460

Cairns SD (1979) The deep-water Scleractinia of the Caribbean Sea and adjacent waters. Stud Fauna Curaçao 57:1-341

Cairns SD (1982) Antarctic and subantarctic Scleractinia. Antarct Res Ser 34:1-74

Cairns SD (1989) A revision of the ahermatypic Scleractinia of the Philippine Islands and adjacent waters, part 1: Fungiacyathidae, Micrabaciidae, Turbinoliinae, Guyniidae, and Flabellidae. Smithson Contrib Zool 486:1-136

Cairns SD (1991) A revision of the ahermatypic Scleractinia of the Galápagos and Cocos Islands. Smithson Contrib Zool 504:1-32

Cairns SD (1994) Scleractinia of the temperate North Pacific. Smithson Contrib Zool 557:1-107

Cairns SD (1995) The marine fauna of New Zealand: scleractinia (Cnidaria: Anthozoa). N Z Oceanogr Inst Mem 103:1-210

Cairns SD (2000) A revision of the shallow-water azooxanthellate Scleractinia of the Western Atlantic. Stud Natl Hist Caribb Reg $75: 1-240$

Cairns SD (2004) The azooxanthellate Scleractinia (Coelenterata: Anthozoa) of Australia. Rec Aust Mus 56:259-329

Cairns SD (2007) Deep-water corals: an overview with special reference to diversity and distribution of deep-water scleractinian corals. Bull Mar Sci 81:311-322

Cairns SD (2010) Cold water corals. Phylogenetic list of 722 valid recent azooxanthellate scleractinian species, with their junior synonyms and depth ranges. http://www.lophelia.org/pdf/Coldwater_Corals_Online_Appendix_000.pdf. (revised 07/2010). Accessed 25 Dec 2013
Cairns SD, Chapman RE (2001) Biogeographic affinities of the North Atlantic deep-water Scleractinia. In: Willison JHM, Hall J, Gass SE, Kenchington ELR, Butler M, Doherty P (eds) Proceedings of the first international symposium on deep-sea corals. Action Centre, Halifax, pp 30-57

Cairns SD, Parker SA (1992) Review of the recent Scleractinia (stony corals) of South Australia, Victoria and Tasmania. Rec S Aust Mus Monogr Ser 3:1-82

Castric-Fey A (1996) Le Scléractiniaire Dendrophyllia cornigera en eau profonde à Ouessant (Bretagne, Atlantique NE) en l'absence de barrière thermique. Oceanol Acta 19:665-671

Castric-Fey A, Girard-Descatoire A, l'Hardy-Halos MT, DerrienCourtel S (2001) La vie sous-marine en Bretagne. Découverte des fonds rocheux. ADMS, Concarneau, pp 176

Cristobo J, Ríos P, Sánchez F, Anadón N (2009) Redescription of the rare species Podospongia loveni (Porifera) from the Cantabrian Sea. Cont Shelf Res 29:1157-1164

de Folin L (1887) Sous les mers: campagnes d'exploration du Travailleur et du Talismán. J. B. Baillière et fils, Paris

de Folin L, Périer L (1875) Exploration bathométrique de la fosse de Cap-Breton. Campagne de, 1871. In: de Folin L, Périer L (eds) Les fonds de la mer. Savy, Paris, pp 29-34

de Pourtalès LF (1868) Contributions to the fauna of the Gulf stream at great depths (2d series). Bull Mus Comp Zool 1:121-141

de Pourtalès LF (1878) Reports on the results of dredging, under the supervision of Alexander Agassiz, in the Gulf of Mexico, by the U. S. coast survey steamer "Blake". Corals. Bull Mus Comp Zool 5:197-212

Duncan V (1873) A description of the Madreporaria dredged up during the expeditions of "H. M. S. Porcupine" in 869 and 1870 Part I. Trans Zool Soc Lond 8(303-344):39-49

Fischer P (1872) Crustacés Podophthalmaires et Cirrhipèdes du département de la Gironde et des côtes du Sud-Ouest de la France. Actes Soc Linn Bordx 28:405-438

Fricke HW, Schuhmacher H (1983) The depth limits of Red Sea stony corals: an ecophysiological problem (a deep diving survey by submersible). P S Z N I Mar Ecol 4:163-194

Gourret P (1906) Lophohelia prolifera, Amphihelia rostrata, Amphihelia oculata. In: Marion AF (ed) Étude des Coelentérés atlantiques recueillies par la Commission de dragages de l'aviso le Travailleur durant les campagnes 1880 et 1881 . Masson and Cie, Paris, pp 121-122

Gravier C (1915) Note préliminaire sur les Madréporaires recueillis au cours des croisières de la Princesse-Alice et de l'Hirondelle II, de 1893 a 1913 inclusivement. Bull Inst Océanogr 12:1-304

Gravier C (1920) Madréporaires provenant des campagnes des yachts Princesse Alice et Hirondelle II (1893-1913). Résult Camp Scient Prince Albert 55:1-123

Huston MA (1985) Patterns of species diversity on coral reefs. Annu Rev Ecol Syst 16:149-177

Joubin L (1922a) Les coraux de mer profonde nuisibles aux chalutiers. Notes Mem Off Sci Tech Peches Marit 18:1-16

Joubin L (1922b) Distribution géographique de quelques coraux abyssaux dans les mers occidentales européens. C R Hebd Seance Acad Sci Paris 175:930-933

Jourdan E (1895) Zoanthaires provenant des campagnes du yacht l'Hirondelle (Golfe de Gascogne, Açores, Terre-Neuve). Résult Camp Scient Prince Albert I 8:1-36

Kitahara MV (2007) Species richness and distribution of azooxanthellate scleractinia in Brazil. Bull Mar Sci 81:497-518

Kitahara MV, Cairns SD (2009) A revision of the genus Deltocyathus Milne Edwards and Haime, 1848 (Scleractinia, Caryophylliidae) from New Caledonia, with the description of a new species. Zoosystema 31:233-248 
Kitahara MV, Cairns SD, Miller DJ (2010) Monophyletic origin of Caryophyllia (Scleractinia, Caryophylliidae), with descriptions of six new species. Syst Biodivers 8:91-118

Lavaleye MSS, Duinevald GCA, Berghuis EMK, Ok A, Witbaard R (2002) A comparison between the megafauna communities on the N.W. Iberian and Celtic continental margins: effects of coastal upwelling? Prog Oceanogr 52:459-476

Le Danois E (1948) Les profondeurs de la mer. Trente ans de recherches sur la faune sous-marine au large des côtes de France. Payot, Paris

Lindström G (1877) Contributions to the actinology of the Atlantic Ocean. K Svenska Vetensk Akad Handl 14:1-26

Louzao M, Anadón N, Arrontes J, Álvarez Claudio C, Fuente M, Ocharán F, Anadón A, Acuña JL (2010) Historical macrobenthic community assemblages in the Avilés Canyon, N Iberian Shelf: baseline biodiversity information for a marine protected area. J Mar Syst 80:47-56, supplementary data at doi: 10.1016/j. jmarsys. 2009.09.006

Marion AF (1906) Étude des Coelentérés atlantiques recueillis par la commission de dragages de l'aviso le "Travailleur" durant les campagnes 1880 et 1881 (oeuvres posthumes de A.F. Marion réunies par Paul Gourret). Masson and Cie, Paris

Menzies RJ, George RY, Rowe GT (1973) Abyssal environment and ecology of the world oceans. John Wiley, New York

Milne Edwards A (1882) Rapport sur les travaux de la comisión chargée par M. le ministre de l'instruction publique d'étudier la fauna sous-marine dans les grands profondeurs de la Méditerranée et de l'océan Atlantique. Arch Missions Scient Littér (3)9: $1-59$

Molodtsova T, Sanamyan NP, Keller NB (2008) Anthozoa from the northern Mid-Atlantic Ridge and Charlie-Gibbs Fracture Zone. Mar Biol Res 4:112-130

Monteiro Marques V, Andrade F (1981) Contribution à l'étude du bathyal rocheux des cotes ibériques. Arq Mus Bocage B I 8:81-96

OSPAR (2008) Directrices para la identificación y selección de áreas marinas protegidas en el área marítima de Ospar. Formulario de las características de una potencial área marina protegida. El Cachucho. OSPAR Commission, 2003-2017, pp 44

Paulmier G (1997) Atlas des invertébrés du Golfe de Gascogne inventoriés dans les captures des chaluts-campagnes Ressgasc 1992-1995 et Evhoe 1995. Ifremer, L'Houmeau

Rallo A, García-Arberas L, Isasi I (1993) Fauna macrobéntica de los fondos del cañón de Capbretón: análisis faunístico de poliquetos, crustáceos y cnidarios y caracterización de puntos de muestreo según estos descriptores. Cah Biol Mar 35: 69-90

Ramil Blanco FJ, Fernández Pulpeiro E (1990) Inventario de los Antozoos de Galicia. Bol R Soc Esp Hist Nat Sec Biol 86:17-30

Reveillaud J, Freiwald A, Van Rooij D, Le Guilloux E, Altuna Á, Foubert A, Vanreusel A, le Olu-Roy K, Henriet JP (2008) The distribution of scleractinian corals in the Bay of Biscay, NE Atlantic. Facies 54:317-331

Reyes J, Santodomingo N, Cairns SD (2009) Caryophylliidae (Scleractinia) from the Colombian Caribbean. Zootaxa 2262:1-39

Roule L (1896) Coelentérés. Resultats scientifiques de la campagne du "Caudan" dans le Golfe de Gascogne, août-septembre 1895. Ann Univ Lyon 26:299-323

Sánchez F (2009) ECOMARG 09. Plan de Campaña. Proyecto ECOMARG-3. Seguimiento del AMP de "El Cachucho" e identificación de ecosistemas relevantes en las plataformas de Galicia y Mar Cantábrico. Gobierno de España, Ministerio de Medio Ambiente Rural y Marino, Madrid

Sánchez Delgado F, Serrano A (2010) INDEMARES 0710. Plan de campaña. Gobierno de España. Ministerio de Ciencia e Innovación, Madrid
Sánchez F, Serrano A, Parra S, Ballesteros M, Cartes JE (2008) Habitat characteristics as determinant of the structure and spatial distribution of epibenthic and demersal communities of Le Danois Bank (Cantabrian Sea, N. Spain). J Mar Sys 72:64-86

Sánchez F, Serrano A, Ballesteros MG (2009) Photogrammetric quantitative study of habitat and benthic communities of deep Cantabrian Sea hard grounds. Cont Shelf Res 29:1174-1188

Sánchez F, Cristobo J, Ríos P, Sánchez-Pola C, Parra S, Lourido A, Druet M, Rivera J, Frutos I (2012) Informes de las campañas INDEMARES-AVILÉS 0412 e INDEMARES-AVILÉS 0912. Gobierno de España, Ministerio de Economía y Competitividad, Madrid

Sánchez F, González-Pola C, Acosta J, Druet M, Cristobo J, GarcíaAlegre A, Parra S, Ríos P, Altuna Á, Gómez-Ballesteros M, Muñoz-Recio A, Rivera J, del Díaz Río G (2014) Habitat characterization of deep-water coral reefs on the La Gaviera Canyon: Deep-Sea Res II. Avilés Canyon System, Cantabrian Sea. doi:10.1016/j.dsr2.2013.12.014

Sars GO (1872) On some remarkable forms of animal life from the great deeps off the Norwegian coast. GrØgger and Christie, Christiania

Schröder-Ritzrau A, Freiwald A, Mangini A (2005) U/Th-dating of deep-water corals from the eastern North Atlantic and the western Mediterranean Sea. In: Freiwald A, Roberts JM (eds) Cold-water corals and ecosystems. Springer Verlag, Heidelberg, pp 157-172

Serrano A, Sánchez F, García-Castrillo G (2006) Epibenthic communities of trawlable grounds of the Cantabrian Sea. Sci Mar 70S1:149-159

Serrano A, Sánchez F, Punzón A, Velasco F, Olaso I (2011) Deep sea megafaunal assemblages off the northern Iberian slope related to environmental factors. Sci Mar 75:425-437

Verrill AE (1883) Report on the Anthozoa, and on some additional species dredged by the "Blake" in 1877-1879, and by the U.S. Fish Commission steamer "Fish Hawk" in 1880-1882. Bull Mus Comp Zool 11:1-72

Von Marenzeller E (1904) Steinkorallen. Wiss Ergebn Dt TiefseeExped 'Valdivia' 1898-1899 7:261-318

Zibrowius H (1974) Caryophyllia sarsiae $\mathrm{n}$. sp. and other recent deepwater Caryophyllia (Scleractinia) previously referred to little known fossil species (C. arcuata, C. cylindracea). J Mar Biol Ass UK 54:769-784

Zibrowius H (1980) Les Scléractiniaires de la Méditerranée et de l'Atlantique nord-oriental. Mém Inst Océanogr Monaco $11: 1-284$

Zibrowius H (1985) Scleractiniaires. In: Laubier L, Monniot C (eds) Peuplements profonds du Golfe de Gascogne. Campagnes Biogas, Ifremer, Brest, pp 311-324

Zibrowius H, Gili JM (1990) Deep-water Scleractinia (Cnidaria: Anthozoa) from Namibia, South Africa, and Walvis Ridge, southeastern Atlantic. Sci Mar 54:19-46

Zibrowius H, Grygier MJ (1985) Diversity and range of scleractinian coral hosts of Ascothoracida (Crustacea: maxillopoda). Ann Inst Océanogr Paris 61:115-138

Zibrowius H, Saldanha L (1976) Scléractiniaires récoltés en plongée au Portugal et dans les archipels de Madère et des Açores. Bolm Soc Port Ciênc Nat 16:91-114

Zibrowius H, Southward EC, Day JH (1975) New observations on a little-known species of Lumbrineris (Polychaeta) living on various Cnidarians, with notes on its recent and fossil Scleractinian hosts. J Mar Biol Ass UK 55:83-108 